(C) 2021, The Authors. Published by Elsevier Inc. and Fass Inc. on behalf of the American Dairy Science Association ${ }^{\circledR}$. This is an open access article under the CC BY-NC-ND license (http://creativecommons.org/licenses/by-nc-nd/4.0/).

\title{
Effect of maternal supplementation with essential fatty acids and conjugated linoleic acid on metabolic and endocrine development in neonatal calves
}

\author{
K. L. Uken, ${ }^{1} \odot$ L. Vogel, ${ }^{1}$ M. Gnott, ${ }^{1}$ S. Görs, ${ }^{1}$ C. T. Schäff, ${ }^{1}$ A. Tuchscherer, ${ }^{1}$ A. Hoeflich, ${ }^{1} \odot$ J. M. Weitzel, ${ }^{1} \oplus$ \\ E. Kanitz, ${ }^{1}$ A. Tröscher, ${ }^{2} \odot$ H. Sauerwein, ${ }^{3} \odot$ R. Zitnan, ${ }^{4}$ R. M. Bruckmaier, ${ }^{5} \odot$ J. J. Gross, ${ }^{5} \odot$ W. Liermann, ${ }^{1}$ \\ and H. M. Hammon ${ }^{1 *}$ (1) \\ ${ }^{1}$ Leibniz Institute for Farm Animal Biology (FBN), 18196 Dummerstorf, Germany \\ ${ }^{2}$ BASF SE, 68623 Lampertheim, Germany \\ ${ }^{3}$ Institute of Animal Science, Physiology Unit, University of Bonn, 53115 Bonn, Germany \\ ${ }^{4}$ Institute of Nutrition, Research Institute for Animal Production Nitra, National Agricultural and Food Center, 95141 Luzianky, Slovakia \\ ${ }^{5}$ Veterinary Physiology, Vetsuisse Faculty, University of Bern, 3001 Bern, Switzerland
}

\section{ABSTRACT}

We tested the hypothesis that the maternal supply of essential fatty acids (EFA), especially $\alpha$-linolenic acid, and conjugated linoleic acid (CLA), affects glucose metabolism, the endocrine regulation of energy metabolism and growth, and the intestinal development of neonatal calves. We studied calves from dams that received an abomasal infusion of $76 \mathrm{~g} / \mathrm{d}$ coconut oil (CTRL; $\mathrm{n}=9$ ), $78 \mathrm{~g} / \mathrm{d}$ linseed oil and $4 \mathrm{~g} / \mathrm{d}$ safflower oil (EFA; $\mathrm{n}=9$ ), $38 \mathrm{~g} / \mathrm{d}$ Lutalin (BASF SE) containing $27 \%$ cis- 9 ,trans -11 and trans-10,cis-12 CLA (CLA; $\mathrm{n}=$ 9), or a combination of EFA and CLA (EFA+CLA; n $=11$ ) during the last $63 \mathrm{~d}$ of gestation and early lactation. Calves received colostrum and transition milk from their own dam for the first $5 \mathrm{~d}$ of life. Insulin-like growth factor (IGF)-I, leptin, and adiponectin concentrations were measured in milk. Blood samples were taken before first colostrum intake, $24 \mathrm{~h}$ after birth, and from $\mathrm{d} 3$ to 5 of life before morning feeding to measure metabolic and endocrine traits in plasma. On d 3 of life, energy expenditure was evaluated by a bolus injection of $\mathrm{NaH}^{13} \mathrm{CO}_{3}$ and determination of $\mathrm{CO}_{2}$ appearance rate. On d 4, additional blood samples were taken to evaluate glucose first-pass uptake and ${ }^{13} \mathrm{CO}_{2}$ enrichment after $\left[{ }^{13} \mathrm{C}_{6}\right]$-glucose feeding and intravenous $\left[6,6-{ }^{2} \mathrm{H}_{2}\right]$-glucose bolus injection, as well as postprandial changes in glucose, nonesterified fatty acids (NEFA), insulin, and glucagon. On d 5, calves were killed $2 \mathrm{~h}$ after feeding and samples of small intestinal mucosa were taken for histomorphometric measurements. The concentrations of IGF-I, adiponectin, and leptin in milk decreased during early lactation in all groups, and the concentrations of leptin in first colostrum was higher in

Received December 14, 2020.

Accepted January 22, 2021.

*Corresponding author: hammon@fbn-dummerstorf.de
EFA than in CTRL cows. Plasma glucose concentration before first colostrum intake was higher in EFA calves than in non-EFA calves and was lower in CLA calves than in non-CLA calves. Plasma IGF-I concentration was higher on $\mathrm{d} 1$ before colostrum intake in EFA calves than in EFA+CLA calves and indicated an overall CLA effect, with lower plasma IGF-I in CLA than in non-CLA calves. Postprandial NEFA concentration was lowest in EFA and CLA calves. The postprandial rise in plasma insulin was higher in EFA than in non-EFA calves. Plasma adiponectin concentration increased from d 1 to d 2 in all groups and was higher on d 3 in CLA than in non-CLA calves. Plasma leptin concentration was higher on d 4 and 5 in EFA than in non-EFA calves. Maternal fatty acid treatment did not affect energy expenditure and first-pass glucose uptake, but glucose uptake on d 4 was faster in EFA than in non-EFA calves. Crypt depth was lower, and the ratio of villus height to crypt depth was higher in the ilea of CLA than non-CLA calves. Elevated plasma glucose and IGF-I in EFA calves immediately after birth may indicate an improved energetic status in calves when dams are supplemented with EFA. Maternal EFA and CLA supplementation influenced postprandial metabolic changes and affected factors related to the neonatal insulin response.

Key words: calf, essential fatty acids, conjugated linoleic acid, neonatal energy metabolism

\section{INTRODUCTION}

Due to their indispensability for mammalian growth and development, and mammals' inability to synthesize them, linoleic acid (18:2 cis-9,cis-12) and $\alpha$-linolenic acid (18:3 cis-9,cis-12,cis-15) are classified as essential fatty acids (EFA; Burr and Burr, 1930; Neuringer et al., 1986). These molecules serve as structural components of membranes, acting as ligands that regulate 
transcription factors, and they provide precursors to other molecules that modulate cell metabolism (e. g., in the neural cell during fetal maturation; Innis, 2005). Conjugated linoleic acids, which are predominantly formed in the rumen from EFA and also in the mammary tissue of dairy cows (Bauman et al., 2000), can also act as ligands for transcription factors, modulate the synthesis of lipids (Moya-Camarena et al., 1999; Harris et al., 2001), and influence metabolic processes in dairy cows (Baumgard et al., 2000; Odens et al., 2007; Hötger et al., 2013). The cow's supply of these fatty acids has changed as a result of replacing pasture and fresh grass with diets based on corn silage in modern dairy cow nutrition. Compared with pasture, corn silage provides high amounts of linoleic acid, but low amounts of $\alpha$-linolenic acid (Ferlay et al., 2006). Furthermore, less CLA is synthesized in cows fed corn silage-based diets than in those fed a pasture or fresh grass diet (Kay et al., 2005; Couvreur et al., 2006). During gestation and via the intake of colostrum and milk, the maternal supply of EFA can be transferred to the calf (Garcia et al., 2014). The first results of the present study showed increased n-3 fatty acid and CLA concentrations, as well as decreased n-6:n-3 fatty acid status in colostrum and in the blood plasma of calves when dams were supplemented with EFA (mainly n-3 fatty acids provided by linseed oil) and CLA (cis9,trans-11 CLA and trans-10,cis-12 CLA) during late gestation and early lactation (Vogel et al., 2020; Uken et al., 2021).

The maternal supply of $\alpha$-linolenic acid and linoleic acid can modulate development and the metabolic processes in calves (Abuelo, 2020). For instance, maternal n-3 supplementation during gestation and lactation might improve intestinal glucose absorption by increasing the number of intestinal glucose transporters, as has been shown in pigs (Gabler et al., 2007). However, in rats an elevated ratio of n- 6 to n-3 in the maternal diet during gestation and lactation favored glucose uptake in the jejunum of the offspring (Jarocka-Cyrta et al., 1998). Furthermore, calves fed milk replacer that provided increased amounts of linoleic and $\alpha$-linolenic acid showed elevated growth performance, had higher glucose concentrations, and tended to have higher IGFI concentrations in plasma (Garcia et al., 2014). In contrast, Hill et al. (2009) and Esselburn et al. (2013) observed a linear decrease in serum glucose and urea in calves when intake of $\alpha$-linolenic acid through linseed oil or commercial product was increased in the starter feed or milk replacer. Interestingly, n-3 fatty acid supplementation improved insulin sensitivity in cattle (Pires et al., 2008), and the gene expression of enzymes related to gluconeogenesis may be under the control of long-chain fatty acids (White et al., 2011). The treat- ment of bovine kidney cells with EFA affected their energy metabolism and fatty acid oxidation (Boesche and Donkin, 2020), and $\alpha$-linolenic acid treatment of bovine kidney cells increased the activity of pyruvate carboxylase promoter 1 (Boesche and Donkin, 2021), a key enzyme that regulates gluconeogenesis in cattle (Donkin, 2016). Furthermore, intestinal morphology might be affected by an enhanced maternal EFA supply during gestation and in the early postnatal phase, as demonstrated in the ilea of piglets whose dams received diets including linseed oil or lard (Boudry et al., 2009). Authors showed reduced villus growth and crypt depth in the ilea of piglets at birth when sows were fed linseed oil during gestation, resulting in elevated n-3 fatty acid status. In contrast, neonatal energy metabolism seems to be less affected by maternal CLA supply in cattle. Petzold et al. (2014) did not find a neonatal metabolic response when cows were fed $100 \mathrm{~g} / \mathrm{d}$ CLA starting at 3 wk before calving.

The present study aimed to investigate the effects of increased maternal supply of EFA and CLA during late gestation and early lactation on neonatal energy metabolism and intestinal mucosal growth in calves. We hypothesized that an enhanced maternal EFA and CLA supply would promote glucose metabolism, especially intestinal glucose uptake, by influencing endocrine factors related to energy metabolism, growth, and intestinal development in neonatal calves during their first $5 \mathrm{~d}$ of life.

\section{MATERIALS AND METHODS}

The experimental procedures were conducted according to German animal-care guidelines and were approved by the authorities of Mecklenburg-West Pomerania, Germany (Landesamt für Landwirtschaft, Lebensmittelsicherheit und Fischerei; LALLF M-V/ TSD/7221.3-1-052/15).

\section{Animals, Experimental Design, and Husbandry}

The present study examined the offspring of 37 German Holstein cows that were evaluated in a comprehensive experiment that investigated the effects of EFA and CLA during late pregnancy and early lactation (Vogel et al., 2020, 2021). The planned number of animals and group size were chosen to ensure a type I error probability of 0.05 and a type II error probability of 0.20 (i.e., power of 0.8 ).

Briefly, dams received corn silage-based diets with a low EFA content, providing particularly low amounts of $\mathrm{n}-3$ fatty acids (1.4 and $9.5 \mathrm{~g}$ of $\mathrm{n}-3$ and $\mathrm{n}-6$ fatty acids per $\mathrm{kg}$ of $\mathrm{DM}$ ) from the middle of the second lactation (wk 22 antepartum) to the 3rd lactation (wk 
9 postpartum). Dams were assigned to 1 of 4 treatments based on milk yield and BW: the control group (CTRL), supplemented with $76 \mathrm{~g} / \mathrm{d}$ coconut oil (BioKokosöl \#665; Kräuterhaus Sanct Bernhard KG); the EFA group, supplemented with EFA in the form of 78 g/d linseed oil (DERBY Leinöl \#4026921003087; Derby Spezialfutter $\mathrm{GmbH}$ ) and $4 \mathrm{~g} / \mathrm{d}$ safflower oil (Gefro Distelöl; Gefro Reformversand Frommlet KG), providing a fatty acid ratio of 1:3 (n-6:n-3) in the supplement mixture; the CLA group, supplemented with $38 \mathrm{~g} / \mathrm{d}$ Lutalin (cis-9,trans-11 and trans-10,cis-12 CLA, 10 g/d each; BASF SE); or the EFA+CLA group, which received a combination of the EFA and CLA supplements $(78 \mathrm{~g} / \mathrm{d}$ linseed oil $+4 \mathrm{~g} / \mathrm{d}$ safflower oil $+38 \mathrm{~g} / \mathrm{d}$ Lutalin). As previously reported by Vogel et al. (2020), the CTRL supplement provided less than $1.4 \mathrm{~g} / \mathrm{d}$ EFA. The EFA supplement provided $39.9 \mathrm{~g} / \mathrm{d}$ o-linolenic acid and $14.9 \mathrm{~g} / \mathrm{d}$ linoleic acid. To compensate for the vitamin $\mathrm{E}$ that naturally occurs in linseed oil, we added vitamin $\mathrm{E}$ to the CTRL and CLA supplements. Cows were fitted with rumen cannulas and abomasal infusion lines, and all supplements were applied via abomasal injection to avoid ruminal biohydrogenation. Fatty acids were infused using $60 \mathrm{~mL}$ catheter-tip syringes twice a day (2 equal portions) at 0700 and $1630 \mathrm{~h}$. All supplements were liquified by heating to $38^{\circ} \mathrm{C}$ to allow infusion (Vogel et al., 2020). Supplementations started $63 \mathrm{~d}$ before expected parturition and continued into early lactation. During the dry period, comprising the last 6 wk of gestation, the amount of supplement was halved. For technical reasons, the calving periods were subdivided into 5 consecutive blocks, with 7 to 8 calves born per block.

The experimental design of the calf study was recently presented in detail in a companion paper (Uken et al., 2021). In total, 38 calves were investigated: 9 in the CTRL group (5 male, 4 female), 9 in the EFA group (4 male, 5 female), 9 in the CLA group (1 male, 8 female), and 11 in the EFA+CLA group (4 male, 7 female; 9 single births and 1 pair of twins: 1 male, 1 female). All calves were separated from their dam immediately after birth. During the experiment, which comprised their first $5 \mathrm{~d}$ of life, calves were housed in a climate-controlled room at $19^{\circ} \mathrm{C}$ in single boxes on straw bedding and with free access to water. The calves were fed colostrum and transition milk from their own dam. If the first colostrum quantity of a dam was insufficient, the required volume was replenished with colostrum from a cow in the same treatment group to ensure a consistent fatty acid supply within treatment groups; this happened 4 times (CTRL and EFA groups). First colostrum was fed $2.5 \pm 1.7 \mathrm{~h}$ after birth on average. Calves were fed with nipple bottles, and calves that refused milk intake were tube-fed to ensure similar in- take. Calves were fed colostrum from the first milking in amounts of $10 \% \mathrm{BW}$ during the first $24 \mathrm{~h}$ after birth, divided into 2 meals. Colostrum from the second milking after calving was fed only if the amount of the first colostrum was not sufficient for the second meal. On d 2 (24 h after birth and before beginning of d 3 of life), calves were fed transition milk from milking 3 after calving. Feed allowance was $6 \%$ of BW on d 2 to ensure that all calves received the same amount of transition milk before d 3 of life, irrespective of whether they were born in the morning or afternoon the day before. From d 3 onwards, the calves were fed transition milk from the 5th, 7th, and 9th milking after calving at $12 \%$ $\mathrm{BW} / \mathrm{d}$, divided into 2 meals (morning and evening). The exact nutrient intakes of the calves are presented in a companion paper (Uken et al., 2021) and reported in Supplemental Table S1 (https://zenodo.org/record/ 4559652). Individual colostrum and transition milk samples from the daily morning and afternoon milkings were collected and stored at $-20^{\circ} \mathrm{C}$ until analysis for IGF-I, leptin, and adiponectin.

\section{Milk Analyses}

Milk serum was obtained in defatted colostrum and transition milk by double centrifugation at $4^{\circ} \mathrm{C}(15 \mathrm{~min}$ at $1,000 \times g)$. Then, the infranatant was centrifuged again $(30 \mathrm{~min}$ at $20,000 \times g)$. The resulting infranatant was used for IGF-I determination by RIA (Vicari et al., 2008). Intra- and interassay coefficients of variation (CV) for IGF-I RIA were less than 10 and 15\%, respectively. Adiponectin in milk was measured by ELISA (Mielenz et al., 2013; Kesser et al., 2015). The intraand interassay $\mathrm{CV}$ were 8.0 and $9.3 \%$, respectively. Milk leptin concentration was determined by ELISA (Sauerwein et al., 2004), and the intra- and interassay CV were 8.1 and $11.4 \%$, respectively. Concentrations of IGF-I, adiponectin, and leptin in colostrum and transition milk in grams per kilogram were computed from concentrations in grams per liter by correcting for the density of milk from the respective milking, according to data from Madsen et al. (2004).

\section{Blood Sampling and Analyses}

Blood was sampled from the jugular vein by venipuncture using evacuated tubes containing $\mathrm{K}_{3}$ EDTA (1.2-2 $\mathrm{mg} \mathrm{K}_{3} \mathrm{EDTA} / \mathrm{mL}$ ) and sodium fluoride/potassium oxalate $(2-4 \mathrm{mg} / \mathrm{L}$ sodium fluoride and $1-3 \mathrm{mg} / \mathrm{L}$ potassium oxalate; Vacuette, Greiner Bio-One International GmbH, Kremsmünster, Austria) on d 1 and 2. From d 3 on, blood was drawn from a catheter (Cavafix Certo with Splittocan, B. Braun Melsungen AG) inserted into the jugular vein; blood was collected in S-Monovette 
tubes containing $\mathrm{K}_{3}$ EDTA $(1.6 \mathrm{mg} / \mathrm{mL}$; Sarstedt AG and Co., Nümbrecht, Germany) and sodium fluoride/ potassium oxalate evacuated tubes (Greiner Bio-One International $\mathrm{GmbH}$ ). Blood samples were placed on ice immediately after collection and subsequently centrifuged at $1,565 \times g$ and $4^{\circ} \mathrm{C}$ for $20 \mathrm{~min}$. The obtained plasma aliquots were stored at $-20^{\circ} \mathrm{C}$ until analysis.

Basal plasma samples were taken for analyses of glucose, fructose, lactate, total protein, urea, triglycerides, nonesterified fatty acids (NEFA), BHB, insulin, glucagon, cortisol, growth hormone, IGF-I, IGF binding proteins (IGFBP)-2, -3, and -4, adiponectin, and leptin before the first colostrum intake on $\mathrm{d} 1$ and before feeding on d 2 to 5 . On d 4, postprandial plasma concentrations of glucose, NEFA, insulin, glucagon, cortisol, and growth hormone were studied by means of hourly plasma samples taken during the first $10 \mathrm{~h}$ (metabolites) or $8 \mathrm{~h}$ (hormones) after the morning feeding. For technical reasons, basal plasma samples were not collected on d 2 to 4 , and postprandial sampling was not conducted in block 2 .

Metabolites were analyzed in plasma containing sodium fluoride and potassium oxalate using an automatic spectrophotometer (ABX Pentra 400; Horiba ABX) and the following kits: glucose (\#A11A01667), lactate (\#A11A01721), and triglycerides (\#A11A01640; Horiba ABX); BHB (\#RB1008) and urea (\#LT-UR 0010; Labor + Technik Eberhard Lehmann GmbH); total protein (\#553-412; MTI Diagnostics); and NEFA (\#434-91795, \#436-91995; Wako Chemicals). Fructose was analyzed in $\mathrm{K}_{3}$ EDTA plasma from $\mathrm{d} 1$ by HPLC as previously described (Metges et al., 2014).

Concentrations of insulin and glucagon were measured in plasma containing $\mathrm{K}_{3}$ EDTA by RIA using corresponding kits (\#RIA-1257, \#RIA-1258; DRG Instruments GmbH, Marburg, Germany) adapted to bovine samples (Hammon et al., 2009). The mean intra- and interassay CV were 6.5 and $11.8 \%$ for insulin and 6.25 and $9.9 \%$ for glucagon, respectively. The revised quantitative insulin sensitivity check index (RQUICKI) was calculated according to the equation of Perseghin et al. (2001),

$$
\begin{gathered}
\text { RQUICKI }=1 /[\log (\text { glucose in } \mathrm{mg} / \mathrm{dL}) \\
+\log (\text { insulin in } \mu \mathrm{U} / \mathrm{mL})+\log (\text { NEFA in mmol/L) },
\end{gathered}
$$

to estimate insulin sensitivity as evaluated for cows by Holtenius and Holtenius (2007). Cortisol in $\mathrm{K}_{3}$ EDTA plasma was analyzed by ELISA as previously reported (Gruse et al., 2016). The intra- and interassay CV were 5.3 and $12.1 \%$, respectively. Concentrations of growth hormone and IGF-I in $\mathrm{K}_{3}$ EDTA plasma were measured by RIA according to Vicari et al. (2008). The intra- and interassay $\mathrm{CV}$ for both measurements were less than 10 and $15 \%$, respectively. Concentrations of IGFBP-2, -3 , and -4 were analyzed in $\mathrm{K}_{3}$ EDTA plasma by quantitative Western ligand blot analysis as described by Wirthgen et al. (2016) and Frieten et al. (2018). The intra- and interassay CV were less than 15 and 20\%, respectively. Concentrations of adiponectin and leptin were determined in $\mathrm{K}_{3}$ EDTA plasma by ELISA; intraand interassay CV were 7.4 and $10.9 \%$ for leptin and 9.7 and $12.7 \%$ for adiponectin, respectively (Sauerwein et al., 2004, Mielenz et al., 2013).

\section{Determination of Energy Expenditure}

The rate of appearance of $\mathrm{CO}_{2}$ was determined as an indirect measure of energy expenditure (Junghans et al., 2007). Thirty calves received an intravenous bolus of $\mathrm{NaH}^{13} \mathrm{CO}_{3}\left(1 \mathrm{mg} / \mathrm{kg}\right.$ BW; 99 atom\% ${ }^{13} \mathrm{C}$; SigmaAldrich) dissolved in $9 \mathrm{~mL}$ of saline $(0.9 \%)$ directly after the morning feeding. Blood samples were collected via catheter on d 3 of life, 15 and $5 \mathrm{~min}$ before and $5,7.5,10,15,20,30,45,60,90,120,150$, and 180 min after tracer application using $\mathrm{K}_{3}$ EDTA Monovettes (Sarstedt AG \& Co). Whole blood was frozen shortly after sampling and stored at $-20^{\circ} \mathrm{C}$ until analysis. The abundance of ${ }^{13} \mathrm{C}$ in blood $\mathrm{CO}_{2}$ was determined according to the protocol published by Junghans et al. (2007), but $500 \mu \mathrm{L}$ of lactic acid was used to release $\mathrm{CO}_{2}$ from $500 \mu \mathrm{L}$ of whole blood. Values for ${ }^{13} \mathrm{C}$ abundance in blood $\mathrm{CO}_{2}$ were converted to atom percent excess and corrected for the mean ${ }^{13} \mathrm{CO}_{2}$ abundance in the blood at both time points before tracer application. Daily energy expenditure was calculated according to Junghans et al. (2007). The sum of 2 exponentials was applied to fit the kinetics of ${ }^{13} \mathrm{C}$ enrichment, and nonlinear regression analysis was conducted as reported by Kaufmann et al. (2011). A recovery factor of 0.81 , as published by Junghans et al. (2007), was chosen to take into account incomplete ${ }^{13} \mathrm{C}$ recovery from blood. A respiratory quotient of 0.76 was applied based on respiration chamber measurements in 2-day-old calves during the first $3 \mathrm{~h}$ after milk feeding (Liermann et al., 2020).

\section{First-Pass Uptake of Glucose}

The first-pass uptake [i.e., the proportion of orally ingested glucose used by the intestine and liver (splanchnic tissue) when it passes the splanchnic tissue for the first time] was determined in a tracer study as described earlier (Schönhusen et al., 2013) and modified according to Gruse et al. (2015). The tracer study was conducted on d 4 and included 29 calves. Briefly, an oral bolus dose of $\left[{ }^{13} \mathrm{C}_{6}\right]$-glucose $(10 \mathrm{mg} / \mathrm{kg} \mathrm{BW} ; 99$ 
atom $\%{ }^{13} \mathrm{C}$; Cambridge Isotope Laboratories, Inc.) dissolved in $9 \mathrm{~mL}$ of saline $(0.9 \%)$ and $\mathrm{D}(+)$-xylose $(0.5 \mathrm{~g} /$ kg BW; 99\% xylose; Carl Roth GmbH + Co. KG) was mixed with $100 \mathrm{~mL}$ of milk and fed to the calves. After application of the oral tracer, an intravenous bolus dose of $\left[6,6{ }^{2} \mathrm{H}_{2}\right]$-glucose $\left(5 \mathrm{mg} / \mathrm{kg} \mathrm{BW} ; 99\right.$ atom $\%{ }^{2} \mathrm{H}$; SigmaAldrich) dissolved in $9 \mathrm{~mL}$ of saline was injected via the jugular vein catheter; the catheter was then thoroughly purged with $20 \mathrm{~mL}$ of saline. Directly after tracer application, the residual morning meal was given. Plasma samples for analyses of $\left[{ }^{13} \mathrm{C}_{6}\right]$ - and $\left[6,6-{ }^{2} \mathrm{H}_{2}\right]$-glucose were taken 15 and 5 min before and 5, 15, 30, 45, 60, 90, 120, $150,180,240,360,480,600$, and 1,440 min after tracer application by catheter using lithium heparinized tubes (12-13 IU heparin/mL; Vacuette; Greiner Bio-One International $\mathrm{GmbH}$ ). Whole blood was collected for measurement of ${ }^{13} \mathrm{CO}_{2}$ enrichment in tubes containing $\mathrm{K}_{3}$ EDTA. The samples were taken 15 and 5 min before and $60,120,150,180,210,240,300,360,480,600$, and 1,440 min after tracer application. For xylose analysis, plasma samples were taken 15 min before and 60, 120, $180,240,300,360,420,480$, and 1,440 min after xylose application in tubes containing $\mathrm{K}_{3} \mathrm{EDTA}$. Whole blood and plasma samples were stored at $-20^{\circ} \mathrm{C}$ until analysis. Xylose concentration in plasma was determined spectrophotometrically as previously reported (Gruse et al., 2015). The enrichment of $\left[{ }^{13} \mathrm{C}_{6}\right]$ - and $\left[6,6-{ }^{2} \mathrm{H}_{2}\right]-$ glucose in plasma was determined by GC-MS as previously described (Junghans et al., 2010). Mean natural abundances in both samples taken before application of the tracer were defined as basal tracer abundance. The rate of appearance of orally and intravenously administered glucose were determined according to the equations of Junghans et al. (2007), and from these the fractional first-pass uptake was calculated as described by Gruse et al. (2015) based on the area under the enrichment curves (AUC; mole percent excess · min). The enrichment of ${ }^{13} \mathrm{C}$ in blood $\mathrm{CO}_{2}$ was analyzed as a measure for glucose oxidation as previously reported (Junghans et al., 2007; Gruse et al., 2015), and the mean abundance of both samples taken before tracer application was used as the basal value.

\section{Sampling and Analyses of Tissues}

Calves were slaughtered $2 \mathrm{~h}$ after feeding on $\mathrm{d} 5$ of life, with the exception of 3 calves, which were slaughtered on d 6 for technical reasons ( 2 calves from group EFA + CLA and 1 calf from group CLA). The weights of the liver, kidney, pancreas, spleen, and thymus were recorded. For morphometric measurements, pieces of the duodenum, mid jejunum, and ileum were sampled, rinsed with saline $(0.9 \%$ ), fixed in Histofix (4\% formaldehyde solution; Carl Roth $\mathrm{GmbH}+\mathrm{Co}$. KG), and stored at $4^{\circ} \mathrm{C}$ until analysis. Morphometric measurements of the small intestine (villus circumference, villus cut surface area, villus height, and crypt depth) were conducted as previously published by Schäff et al. (2018) based on the protocol of Zitnan et al. (2008). Ten images were taken from each segment, and 30 villi and crypts were measured from each segment. The accuracy of 30 villi was tested in previous studies; the CV for measurements in the intestine could be reduced to less than $20 \%$ if at least 30 villi and crypts were evaluated (Blättler et al., 2001).

\section{Statistical Analyses}

Statistical analyses were performed using SAS for Windows (version 9.4; SAS Institute Inc.) using the MIXED procedure. The applied model included the EFA (yes, no) and CLA (yes, no) treatments, time (d relative to calving or min after feeding), block (1 to $5)$, sex, and their respective interactions $(\mathrm{EFA} \times \mathrm{CLA}$; $\mathrm{EFA} \times$ time; CLA $\times$ time; EFA $\times$ CLA $\times$ time) as fixed effects. The duration of maternal supplementation and gestation length were included as covariates. For analyses of milk compounds, the model included the treatments EFA (yes, no) and CLA (yes, no), time (milking relative to parturition), block (1 to 5), and their respective interactions $(\mathrm{EFA} \times \mathrm{CLA}$; EFA $\times$ time; CLA $\times$ time; EFA $\times$ CLA $\times$ time) as fixed effects and the duration of maternal supplementation and gestation length as covariates. Gut morphometry was analyzed using a model including the treatments EFA and CLA, gut segment (duodenum, jejunum, ileum), block, sex, and their interactions $(\mathrm{EFA} \times \mathrm{CLA}$; EFA $\times$ gut segment; CLA $\times$ gut segment; EFA $\times$ CLA $\times$ gut segment) as fixed effects. The REPEATED statement was used to take into account repeated measures on the same calf. For measurements conducted only once per animal (e.g., plasma fructose; AUC for xylose, ${ }^{13} \mathrm{CO}_{2}$, $\left[{ }^{13} \mathrm{C}_{6}\right]$-glucose, and $\left[6,6{ }^{2} \mathrm{H}_{2}\right]$-glucose enrichments; firstpass uptake; rate of appearance of orally administered glucose; rate of appearance of intravenously administered glucose; energy expenditure; and organ weights) a model including the EFA and CLA treatment, block, and sex as fixed effects and the calf as random effect was used. The Tukey-Kramer test was applied to analyze pairwise differences of least squares means (LSM). Partitioned analyses of the LSM for interactions were conducted using the SLICE statement of the MIXED procedure. Results are presented as LSM \pm standard error (SE) unless otherwise stated. Effects were considered significant at $P<0.05$. For analysis of the relationship between metabolite and hormone concentrations in maternal and calf plasma, Spearman's rank correlation was applied using the CORR procedure of 
SAS. Correlations were regarded as significant at $P<$ 0.05 .

\section{RESULTS}

\section{Concentration in Milk and Daily Intake of IGF-I, Adiponectin, and Leptin}

Findings for nutrient content in colostrum and transition milk, as well as nutrient intake, were recently published in a companion paper (Uken et al., 2021), and nutrient intake is presented in Supplemental Table S1 (https://zenodo.org/record/4559652). The concentrations of IGF-I, adiponectin, and leptin in milk decreased $(P<0.001)$ during early lactation in all groups (Table 1). The concentrations of IGF-I in colostrum and transition milk were similar among the groups. The concentrations of adiponectin tended to be affected by maternal CLA supply $(P=0.09)$, with a higher concentration in milking 1 (first colostrum) in the EFA+CLA group than in the CTRL group $(P=0.04)$ and a higher concentration in milking 2 in the CLA group than in the CTRL, EFA, and EFA+CLA groups $(P<0.01)$. The leptin concentration in milking 1 (first colostrum) was higher in the EFA group than in the CTRL group $(P=0.03)$ but remained similar afterward.

The intake of IGF-I did not differ among the groups during the first $5 \mathrm{~d}$ of life (Table 1 ). The intake of adiponectin on $\mathrm{d} 1$ was higher $(P<0.001)$ in CLA calves than in non-CLA calves $(\mathrm{LSM} \pm \mathrm{SE}$ for $\mathrm{CLA}=7.66 \pm$ $0.31 \mathrm{mg} / \mathrm{kg} \mathrm{BW}$ and for non-CLA $=6.22 \pm 0.50 \mathrm{mg} /$ $\mathrm{kg} \mathrm{BW})$ and higher $(P=0.04)$ in CLA calves than in CTRL calves. The intake of leptin on $\mathrm{d} 1$ was higher in EFA and CLA calves than in CTRL calves $(P<0.05)$.

\section{Metabolites and Hormones in Basal Blood Samples}

Plasma glucose concentrations directly after birth and before first colostrum intake were higher in EFA calves than in CTRL and CLA calves $(P<0.05$; Table 2). Plasma glucose on $d 1$ was higher $(P<0.05)$ in EFA calves than in non-EFA calves (LSM $\pm \mathrm{SE}$ for $\mathrm{EFA}=$ $5.62 \pm 0.43 \mathrm{mmol} / \mathrm{L}$ and for non-EFA $=4.03 \pm 0.49$ $\mathrm{mmol} / \mathrm{L})$, and was lower $(P<0.05)$ in CLA calves than in non-CLA calves (LSM $\pm \mathrm{SE}$ for $\mathrm{CLA}=4.38 \pm 0.44$ $\mathrm{mmol} / \mathrm{L}$ and for non-CLA $=5.27 \pm 0.48 \mathrm{mmol} / \mathrm{L})$. The basal plasma glucose increased distinctly $(P<0.05)$ from d 1 to $d 2$ of life in non-EFA calves and remained unchanged until d 5 of life. Plasma fructose was measurable only on d 1 of life and did not differ among the groups.

Plasma lactate concentrations decreased $(P<0.001)$ from $\mathrm{d} 1$ to $\mathrm{d} 2$ in all groups but indicated no treatment effects. Plasma BHB concentrations were highest on d 3 of life in all calves, and maternal CLA supplementation tended to affect BHB $(P=0.08)$, with lower concentrations in the CLA group than in the CTRL group on $\mathrm{d}$ $4(P<0.01)$. Plasma concentrations of total protein increased $(P<0.001)$ from $\mathrm{d} 1$ to $\mathrm{d} 2$ in all groups and were higher on $\mathrm{d} 2(P=0.01)$ in CLA calves than in non-CLA calves. Plasma urea concentrations increased $(P<0.001)$ from d 1 to $\mathrm{d} 4$ and decreased $(P<0.001)$ afterward up to $\mathrm{d} 5$ of life in all groups. Calves in the EFA group tended to have lower urea concentrations $(P=0.05)$ than non-EFA calves on d 2 of life (LSM \pm $\mathrm{SE}$ for $\mathrm{EFA}=3.63 \pm 0.77 \mathrm{mmol} / \mathrm{L}$ and for non-EFA $=$ $5.21 \pm 0.86 \mathrm{mmol} / \mathrm{L})$. Plasma concentrations of triglycerides increased $(P<0.05)$ and NEFA decreased $(P<$ 0.001 ) after birth in all groups, but neither metabolite showed treatment effects until d 5 of life.

Basal plasma insulin concentrations did not change with time and were not affected by treatment (Table $2)$. Plasma concentrations of glucagon increased $(P<$ $0.001)$ after birth in all groups and on $\mathrm{d} 2$ were lower $(P$ $<0.05)$ in EFA calves compared with non-EFA calves $(\mathrm{LSM} \pm \mathrm{SE}$ for $\mathrm{EFA}=201.3 \pm 29.3 \mathrm{ng} / \mathrm{L}$ and for non-EFA $=287.2 \pm 30.3 \mathrm{ng} / \mathrm{L})$. The ratio of glucagon to insulin on d 2 was lower $(P=0.03)$ in EFA calves than in non-EFA calves (LSM $\pm \mathrm{SE}$ for $\mathrm{EFA}=0.82$ \pm 0.28 and for non-EFA $=1.59 \pm 0.30$ ). The ratio of glucose to insulin did not respond to the different treatments of the dams. However, the RQUICKI index on $\mathrm{d} 1$ was higher $(P<0.05)$ in the CLA calves than in the non-CLA calves (LSM $\pm \mathrm{SE}$ for CLA $=$ $0.50 \pm 0.03$ and for non-CLA $=0.41 \pm 0.03)$. Plasma cortisol concentrations decreased $(P<0.05)$ and plasma growth hormone concentrations increased $(P$ $<0.05)$ after birth, but the plasma concentrations of both hormones were not affected by maternal fatty acid supplementation. Plasma IGF-I concentrations decreased after birth, were higher $(P<0.05)$ on $\mathrm{d} 1$ of life in EFA calves than in EFA+CLA calves, and indicated an overall CLA effect $(P<0.05)$, with lower plasma IGF-I in CLA calves than in non-CLA calves throughout the study (LSM $\pm \mathrm{SE}$ for CLA $=114.1$ $\pm 14.7 \mu \mathrm{g} / \mathrm{L}$ and for non-CLA $=139.2 \pm 15.9 \mu \mathrm{g} / \mathrm{L})$. Plasma concentrations of IGFBP-3 increased from d 1 to 2 in all groups except for the CTRL group $(P<$ 0.01 ), and higher concentrations were observed on $\mathrm{d} 2$ in EFA calves than in non-EFA calves $(P=0.04$; LSM $\pm \mathrm{SE}$ for $\mathrm{EFA}=2,240 \pm 179 \mu \mathrm{g} / \mathrm{L}$ and for non-EFA $=1,868 \pm 202 \mu \mathrm{g} / \mathrm{L})$. Ratios of IGFBP-3 to IGFBP-2 in plasma increased $(P<0.001)$ from d 1 to $\mathrm{d} 2$, and ratios were higher $(P<0.05)$ on $d 2$ in EFA calves than in EFA +CLA calves. Plasma IGFBP-4 concentrations increased $(P<0.05)$ from d 1 to $\mathrm{d} 2$ in all groups and remained elevated until d 5 but did not show effects with respect to maternal fatty acid treatment. Plasma 
Uken et al.: MATERNAL FATTY ACID SUPPLY IN CALVES

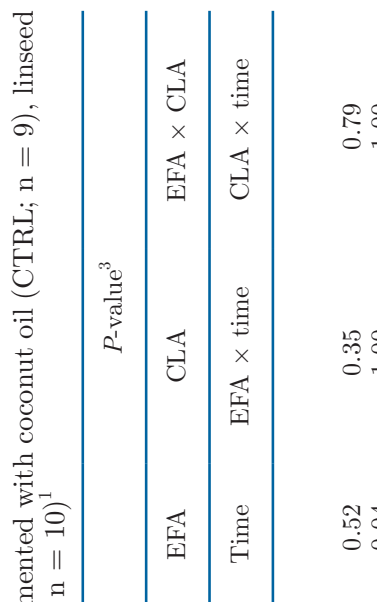

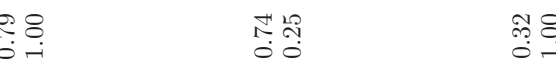

คูำ

î.

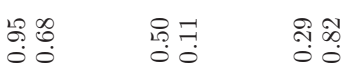

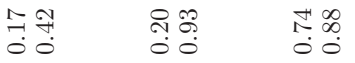

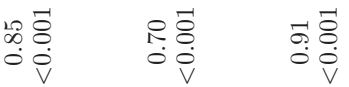

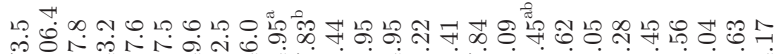

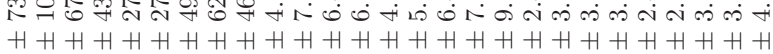

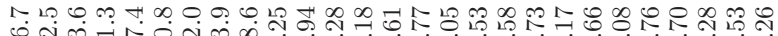

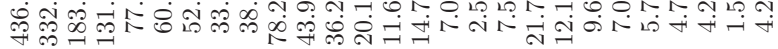

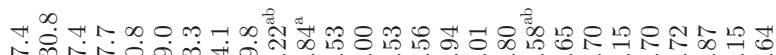

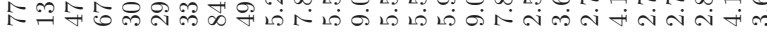
$H+H+H+H+H+H H+H+H+H+H+H+H+H+H+H+H+H+H+H$

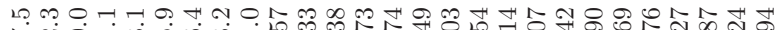

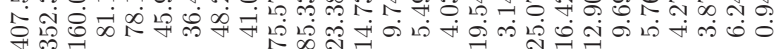

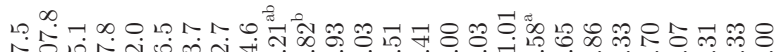

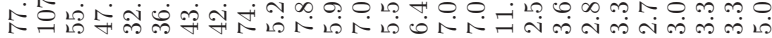
$H+H+H+H+H+H+H+H+H+H+H+H+H+H+H+H+H H+H$

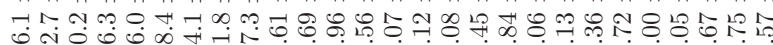

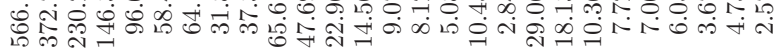

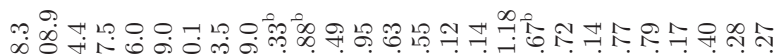

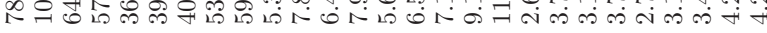
$H+H+H+H+H+H+H+H+H+H+H+H+H+H+H+H+H+H+$

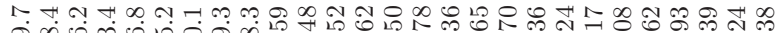

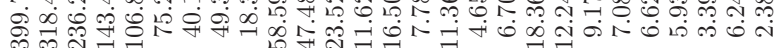

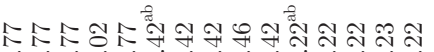
ง $\mathrm{H} H \mathrm{H} H \mathrm{H} H \mathrm{H} H \mathrm{H} H+\mathrm{H} H+\mathrm{H} H$

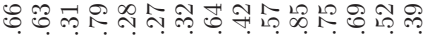

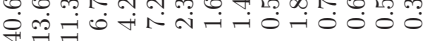

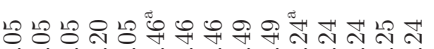

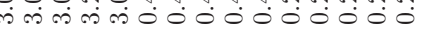
$H+H+H+H+H+H+H+H+H+H+$

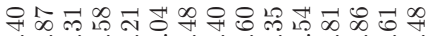

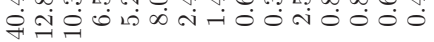

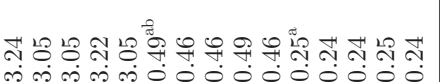
$H+H+H+H+H+H+H+H+H+H$

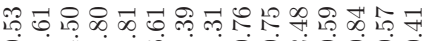

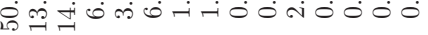

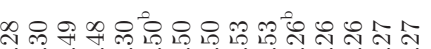

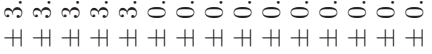

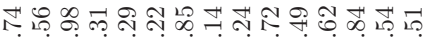

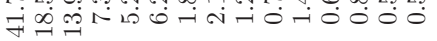

思

HNm

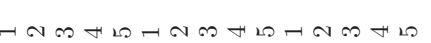

氙

过节

光㲾

:

慈

볼

वृ.

-

垔

๘ี

$\pm 10 \%$

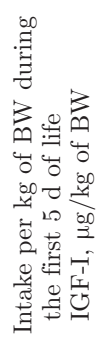

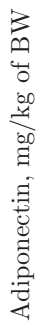

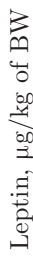

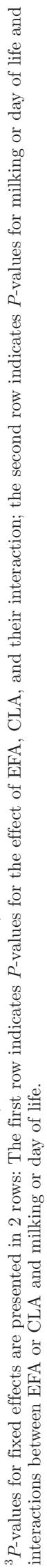


Uken et al.: MATERNAL FATTY ACID SUPPLY IN CALVES

7302

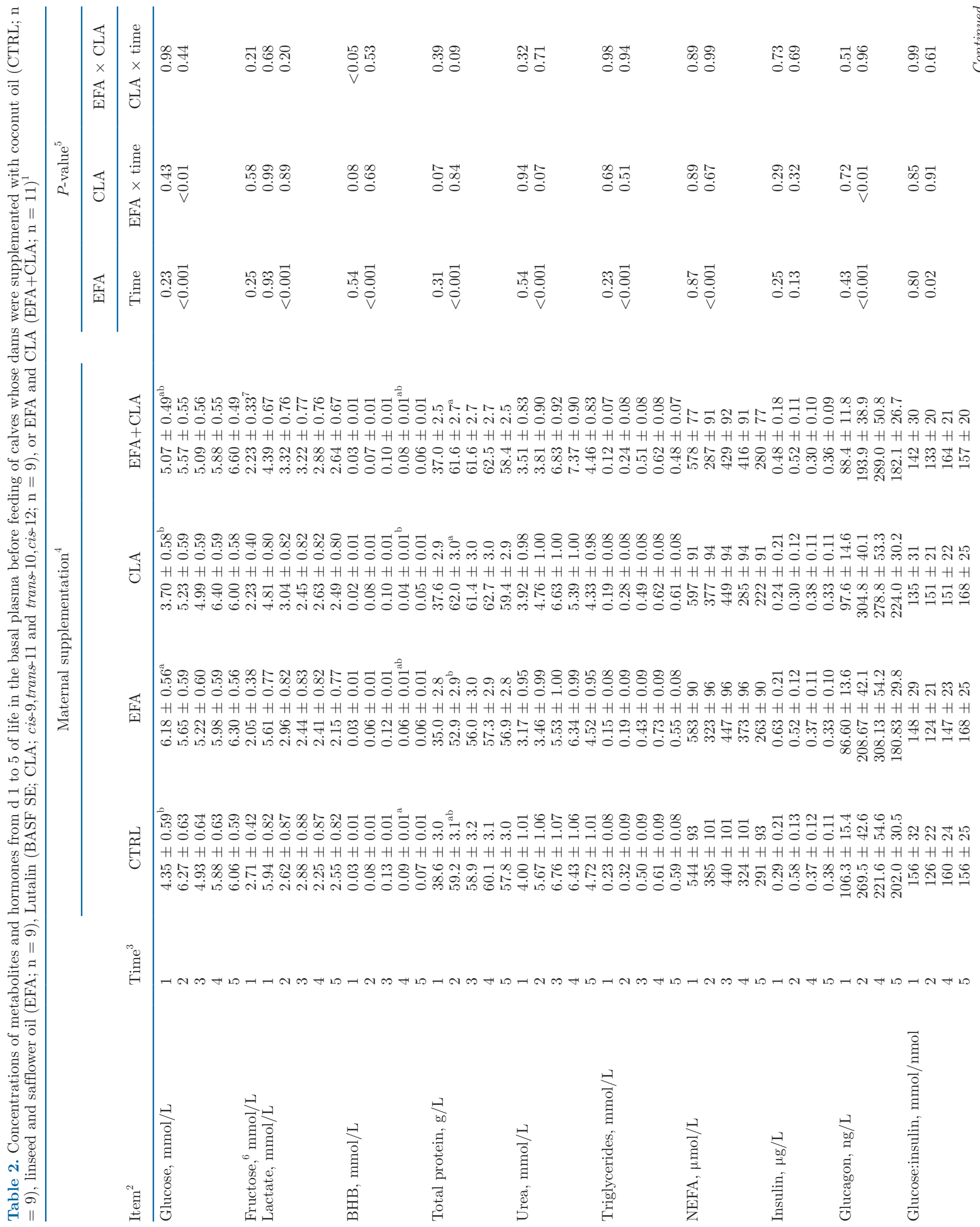


Uken et al.: MATERNAL FATTY ACID SUPPLY IN CALVES

7303

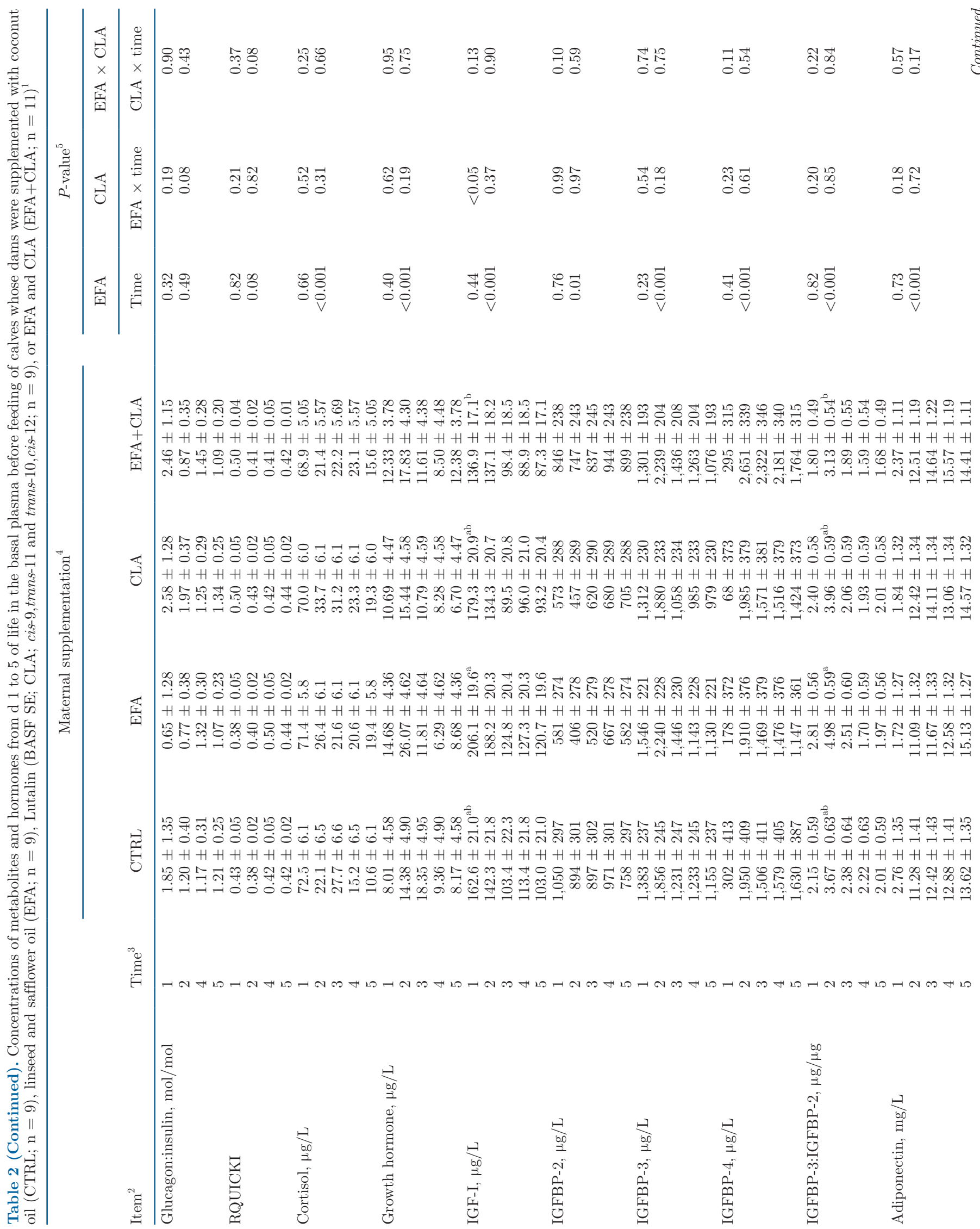


adiponectin concentrations increased $(P<0.001)$ from d 1 to $\mathrm{d} 2$ in all groups, remained elevated throughout the study, and were higher $(P=0.03)$ on d 3 in CLA calves than in non-CLA calves (LSM $\pm \mathrm{SE}$ for CLA $=$ $14.4 \pm 1.1 \mathrm{mg} / \mathrm{L}$ and for non-CLA $=12.0 \pm 1.1 \mathrm{mg} / \mathrm{L}$ ). Plasma concentrations of leptin increased from $\mathrm{d} 1$ to 2 in calves from the EFA and EFA+CLA groups $(P<$ $0.05)$ and were higher $(P<0.05)$ on $\mathrm{d} 4$ and 5 in EFA calves than in non-EFA calves (LSM $\pm \mathrm{SE}$ on $\mathrm{d} 4$ for $\mathrm{EFA}=4.82 \pm 0.63 \mu \mathrm{g} / \mathrm{L}$ and for non-EFA $=3.49 \pm$ $0.71 \mu \mathrm{g} / \mathrm{L}$; on $\mathrm{d} 5$ for EFA $=4.79 \pm 0.60 \mu \mathrm{g} / \mathrm{L}$ and for non-EFA $=3.50 \pm 0.69 \mu \mathrm{g} / \mathrm{L})$.

Plasma concentrations of glucose in calves before first colostrum intake were positively correlated with plasma insulin ( $\mathrm{r}=0.32 ; P=0.05)$ and maternal plasma glucose at parturition $(\mathrm{r}=0.37 ; P<0.05)$. Plasma concentrations of fructose in calves before first colostrum intake were positively correlated with plasma insulin (r $=0.51 ; P<0.01)$ and leptin $(\mathrm{r}=0.54 ; P<0.001)$, and plasma insulin was positively correlated with plasma leptin $(\mathrm{r}=0.36 ; P<0.05)$. Plasma concentrations of IGF-I in the calves before first colostrum intake were negatively correlated with plasma lactate $(\mathrm{r}=-0.34 ; P$ $<0.05)$ and positively correlated with maternal plasma IGF-I at parturition $(\mathrm{r}=0.36 ; P<0.05)$; maternal plasma IGF-I concentrations were negatively correlated with plasma urea in calves at birth $(\mathrm{r}=-0.57 ; P<$ 0.001). Plasma concentrations of adiponectin in calves before first colostrum intake were negatively correlated with maternal plasma concentrations of glucose and insulin at parturition $(\mathrm{r}=-0.36$ and $-0.34 ; P<0.05$, respectively).

\section{Postprandial Changes in Metabolites and Hormones on $d 4$}

Plasma concentrations of glucose increased after feeding in all groups except for the CTRL group $(P<$ 0.05; Figure 1A). Basal glucose levels were exceeded 60 min after feeding in the EFA and EFA+CLA groups and 120 min after feeding in the CLA group $(P<0.05)$. Plasma concentrations of lactate were lower in the EFA group than in the EFA+CLA group at 600 min after feeding $(P<0.05$; Supplemental Figure S1A, https:// zenodo.org/record/4559652). Plasma NEFA concentrations decreased $(P<0.05)$ after feeding in all groups except the CTRL group (Figure 1B). Plasma NEFA concentrations were lower $(P<0.05)$ in the EFA group than in the CTRL group at 120 and 300 min after feeding and were lower $(P<0.05)$ in the CLA group than the CTRL group at 240 min after feeding. Plasma NEFA concentrations were higher $(P<0.05)$ at $60 \mathrm{~min}$ after feeding in CLA calves than in non-CLA calves. Postprandial plasma concentrations of triglycerides and 
urea resembled basal levels and were similar between groups (Supplemental Figure S1B, C).

Plasma insulin concentrations increased $(P<0.01)$ after feeding in all groups (Figure 2A). Plasma insulin was higher $(P<0.05) 60$ min after feeding in the EFA group than in the CLA group and 120 min after feeding in the EFA+CLA group than in the CTRL group. Plasma concentrations of glucagon decreased only in the calves of the EFA group 60 min after feeding $(P$ $<0.01$; Figure 2B). Ratios of glucose to insulin and glucagon to insulin decreased $(P<0.001)$ immediately after feeding, and the ratio of glucose to insulin was lower $(P<0.01)$ in EFA calves than in non-EFA calves at 420 min after feeding. The ratio of glucagon to insulin was higher $(P<0.05)$ at $360 \mathrm{~min}$ in CLA calves than in non-CLA calves, and it was lower $(P<0.05)$ at 420 min after feeding in EFA calves than in non-EFA calves (Supplemental Figure S2A, B: https://zenodo .org/record/4559652). Plasma cortisol concentrations decreased $(P<0.05)$ after feeding in all groups except the CTRL group and were higher $(P<0.05)$ at 300 min after feeding in the EFA group than in the CTRL group (Supplemental Figure S2C). Postprandial concentrations of growth hormone in plasma remained unchanged, but plasma growth hormone was higher $(P<0.05)$ at 60 and 120 min in EFA calves than in non-EFA calves (Supplemental Figure S3A). At $60 \mathrm{~min}$ after feeding, plasma growth hormone was higher in the EFA+CLA group than in the CTRL group $(P=0.04)$, and after $240 \mathrm{~min}$, it was higher in the CLA group than in the EFA+CLA and CTRL groups $(P<0.05)$. Compared with the basal values, plasma adiponectin or leptin concentrations did not show postprandial changes (Supplemental Figure S3B, C). However, plasma adiponectin indicated an overall CLA effect, with higher concentrations at 60,120, 240, and 300 min after feeding in CLA calves than in non-CLA calves.

\section{Energy Expenditure and First-Pass Uptake of Glucose}

Energy expenditure on d 3 was (LSM \pm SE) $803 \pm$ $93,910 \pm 77,775 \pm 78$, and $805 \pm 74 \mathrm{~kJ} / \mathrm{d} \times \mathrm{kg} \mathrm{BW}{ }^{0.75}$ in the CTRL, EFA, CLA, and EFA+CLA calves, respectively, but did not differ among groups. Plasma concentrations of xylose increased in all groups after feeding and were lower in EFA calves than in non-EFA calves at 360 and $420 \mathrm{~min}$ after oral xylose administration $(P<0.05$; Figure $3 \mathrm{~A})$. Nevertheless, the AUC of plasma xylose concentration was similar among the groups $(\mathrm{LSM} \pm \mathrm{SE} ; 1,866 \pm 80,1,661 \pm 64,1,669 \pm$ 66 , and $1,704 \pm 61 \mathrm{mmol} / \mathrm{L} \times \min$ for the CTRL, EFA, CLA, and EFA+CLA groups, respectively). Enriched $\left[{ }^{13} \mathrm{C}_{6}\right]$-glucose levels exceeded basal values after feeding in all groups $(P<0.05$; Figure $3 \mathrm{~B})$. Moreover, $\left[{ }^{13} \mathrm{C}_{6}\right]$ glucose enrichment at 15 and 30 min after feeding was higher in EFA calves than in non-EFA calves $(P<$ $0.05)$, and $\left[{ }^{13} \mathrm{C}_{6}\right]$-glucose enrichment at 5 and $15 \mathrm{~min}$ after feeding was higher $(P<0.05)$ in the EFA+CLA group than in the CLA group. Nevertheless, the rate of appearance of orally administered glucose, the rate of appearance of intravenously administered glucose, and first-pass uptake with or without correction for xylose absorption were similar among groups (Table 3 ). Enrichment of ${ }^{13} \mathrm{CO}_{2}$ in blood at 360 min after feeding
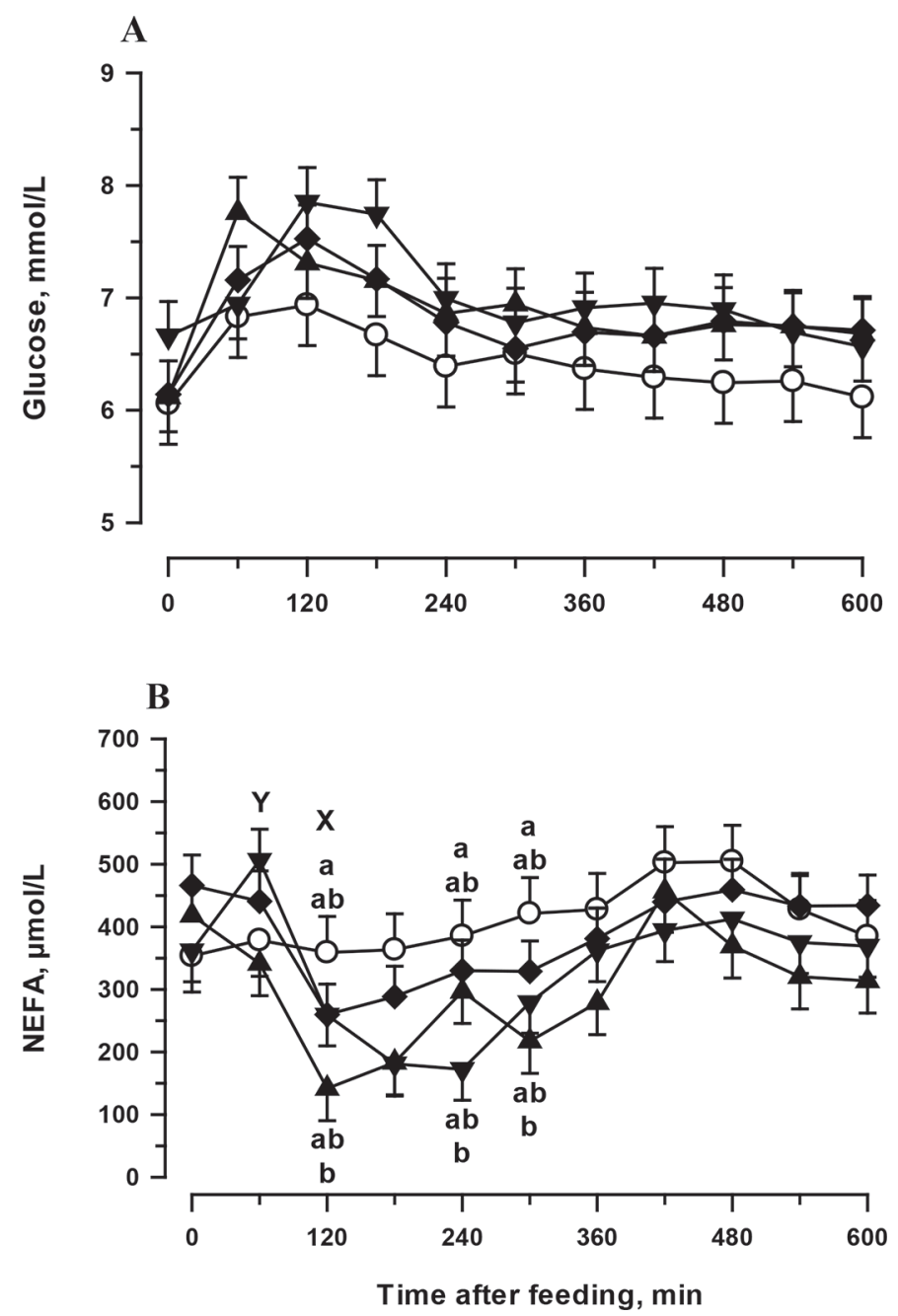

Figure 1. Postprandial concentrations of (A) glucose and (B) nonesterified fatty acids (NEFA) on d 4 of life in the plasma of calves whose dams were supplemented with coconut oil (CTRL; $\mathrm{O} ; \mathrm{n}=6 ; 1$ calf was excluded due to fever), linseed and safflower oil (EFA; $\mathbf{\Lambda} ; \mathrm{n}$ $=7$ ), Lutalin (BASF SE; CLA; cis-9,trans-11 and trans-10,cis-12; $\mathbf{v}$; $\mathrm{n}=8$ ), or EFA and CLA (EFA+CLA; $\$ \mathrm{n}=8$ ). Data are presented as LSM and SE. Different letters $(\mathrm{a}, \mathrm{b})$ represent significant differences among groups at the same time point $(P<0.05)$. X indicates significant differences between EFA and non-EFA calves; Y indicates significant differences between CLA and non-CLA calves. Significant effects $(P<0.05)$ for glucose (time, EFA $\times$ time, and CLA $\times$ time interactions) and NEFA (EFA $\times$ CLA interaction and time). 
tended to be lower in EFA calves than in non-EFA calves $(P=0.06$; Figure $3 \mathrm{C})$, whereas the AUC for ${ }^{13} \mathrm{CO}_{2}$ was similar irrespective of maternal treatment.

\section{Organ Development}

The weights of the liver, kidney, pancreas, spleen, and thymus were similar among groups (Supplemental Table S2, https://zenodo.org/record/4559652). Maternal fatty acid supplementation did not affect the villus size of the small intestine (Table 4). However, crypt depth in the ileum was lower in CLA calves than in non-CLA calves $(P=0.03 ; \mathrm{LSM} \pm \mathrm{SE}$ for $\mathrm{CLA}=249$ $\pm 3.5 \mu \mathrm{m}$ and for non-CLA $=255 \pm 3.8 \mu \mathrm{m})$. Consequently, the ileal ratio of villus height to crypt depth was higher in CLA calves than in non-CLA calves $(P=$ $0.04 ; \mathrm{LSM} \pm \mathrm{SE}$ for $\mathrm{CLA}=2.25 \pm 0.06$ and for non$\mathrm{CLA}=2.14 \pm 0.06)$.

\section{DISCUSSION}

\section{Metabolic and Endocrine Changes at Birth}

In a companion paper, we recently showed that changing the maternal supply of EFA and CLA during late gestation and early lactation affected plasma fatty acid concentrations in calves around birth (Uken et al., 2021). Elevated maternal and fetal n-3 fatty acid status resulted in increased plasma glucose concentrations in calves immediately after birth. Because fetal endogenous glucose production is low and calves are often born in a hypoglycemic state, maternal EFA treatment might have improved neonatal glucose status at birth (Fowden et al., 2009; Hammon et al., 2012). Although plasma glucose concentration immediately after birth was positively correlated with maternal plasma glucose, maternal plasma glucose concentration was not affected by fatty acid treatments at parturition (Vogel et al., 2021). We speculate that maternal EFA treatment may have facilitated placental glucose transport during late pregnancy. However, we did not investigate placental glucose transport in the present study. In the literature, a detrimental effect of maternal PUFA administration on placental glucose transport was described in rats (Shrestha et al., 2020). In contrast, the prevalence of placental glucose transporters increased with gestational age in sheep (Ehrhardt and Bell, 1997), and the gestation length tended to be increased in dams receiving EFA compared to dams without EFA supplementation (Uken et al., 2021). Additional studies are needed to investigate the effects of maternal EFA supplementation on placental glucose metabolism in dairy cows. The disappearance of fructose in blood plasma after birth in the present study supports previous findings of elevated plasma fructose in bovine fetuses that was largely metabolized after birth (Kurz and Willett 1992; Tyler and Ramsey, 1993). However, in our study maternal EFA and CLA supplementation did not affect plasma fructose levels in the calves at birth.

Although we found no effect of maternal fatty acid treatment on birth weight, maternal EFA supplementation alone during late gestation resulted in increased plasma IGF-I concentrations in the calves at birth. The somatotropic axis does not control fetal growth, but IGF-I is an important growth factor that stimulates growth and organ development in the fetus (Breier et al., 2000; Gluckman and Pinal, 2003). Because glucose is a main driver of fetal IGF-I (Gluckman and Pinal,
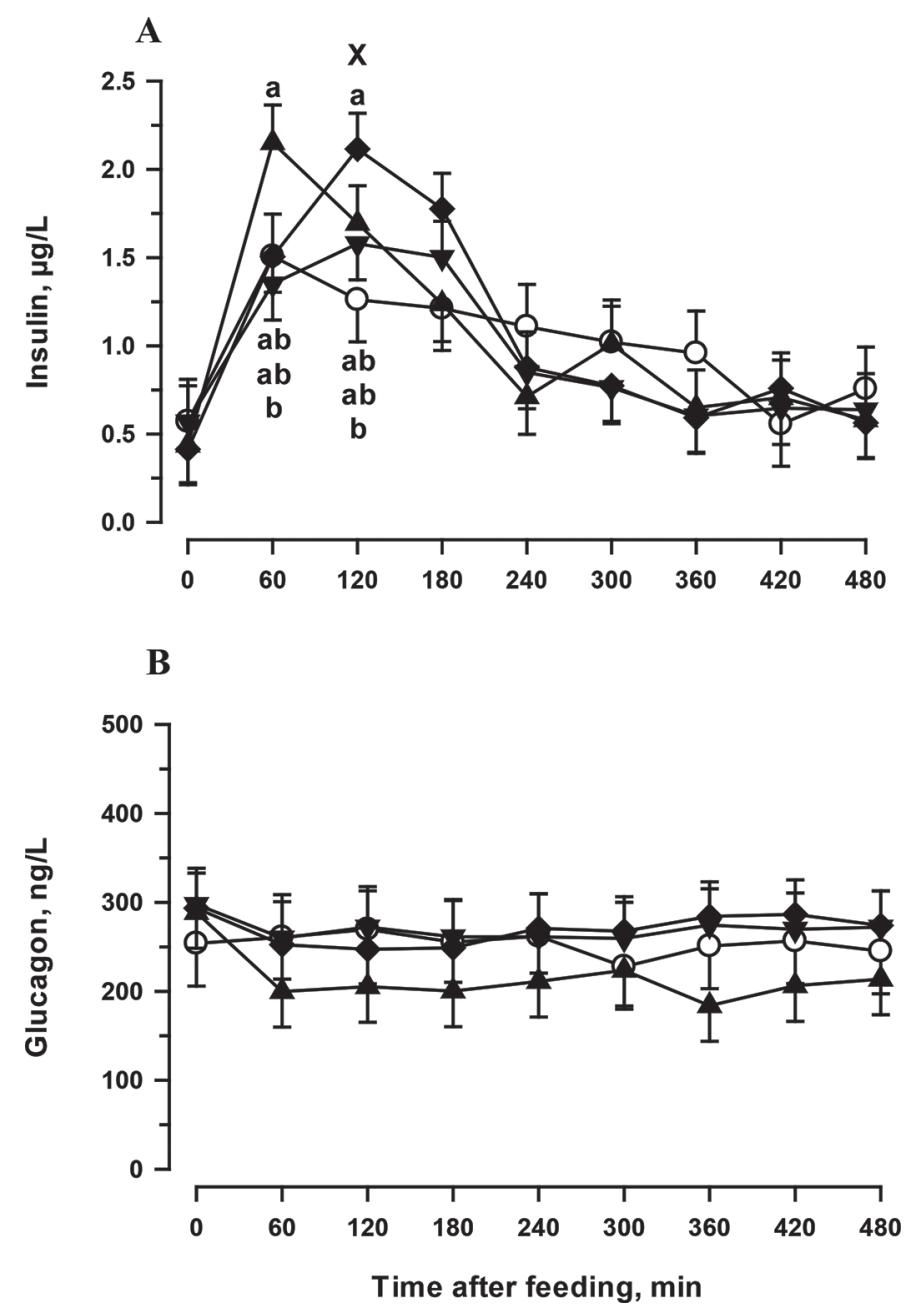

Figure 2. Postprandial concentrations of (A) insulin and (B) glucagon on d 4 of life in the plasma of calves whose dams were supplemented with coconut oil (CTRL; $\mathrm{O} ; \mathrm{n}=6 ; 1$ calf was excluded due to fever), linseed and safflower oil (EFA; $\mathbf{\Delta} ; \mathrm{n}=7$ ), Lutalin (BASF SE; CLA; cis-9,trans-11 and trans-10, cis-12; $\mathbf{v} ; \mathrm{n}=8)$, or EFA and CLA $(\mathrm{EFA}+\mathrm{CLA} ; \boldsymbol{\mathrm { n }}=8)$. Data are presented as LSM and SE. Different letters $(\mathrm{a}, \mathrm{b})$ represent significant differences among groups at the same time point $(P<0.05)$. X indicates significant differences between EFA and non-EFA calves $(P<0.05)$. Significant effects $(P<0.05)$ for insulin (time and CLA $\times$ time interaction) and glucagon (time). 
Uken et al.: MATERNAL FATTY ACID SUPPLY IN CALVES

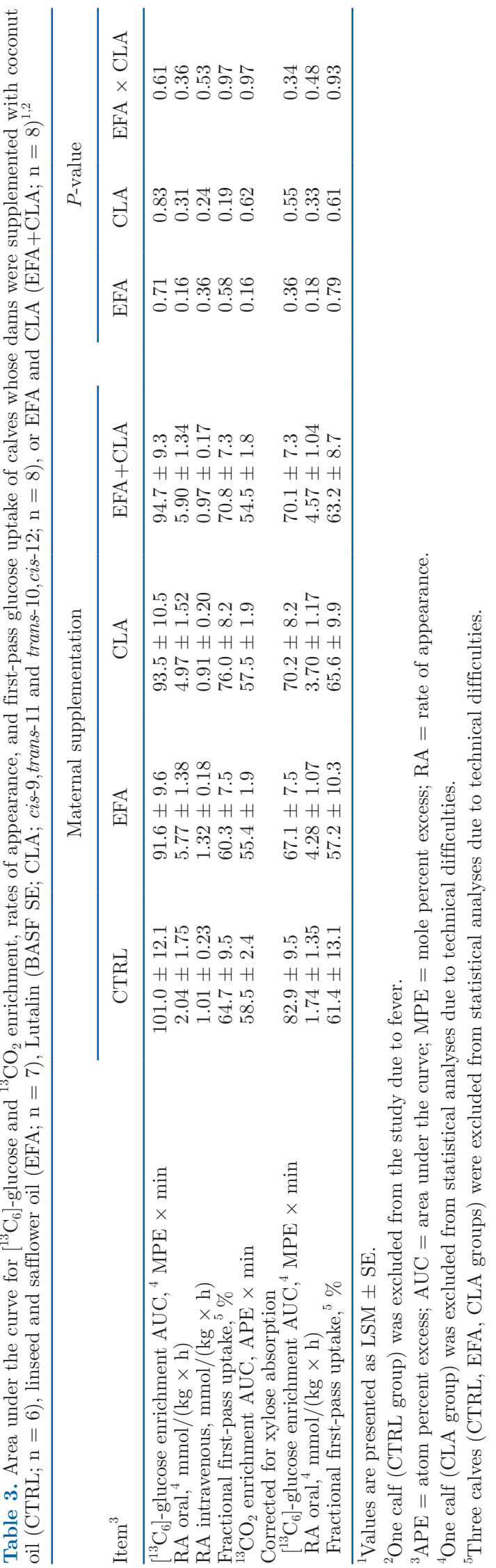

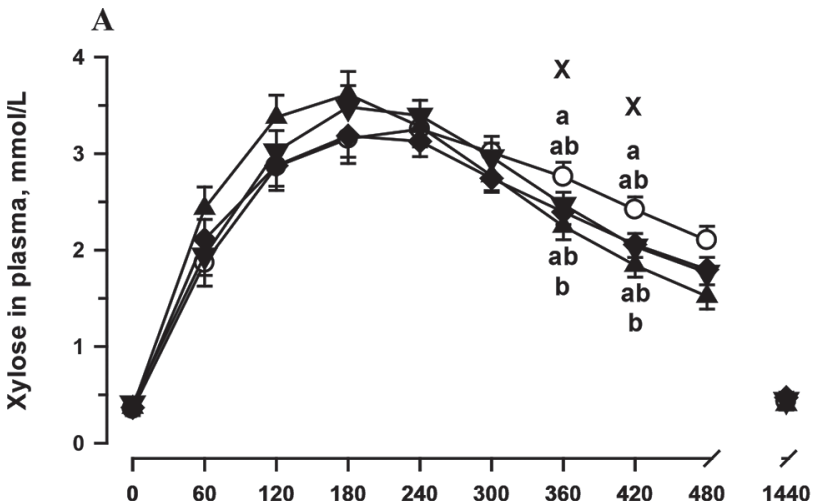
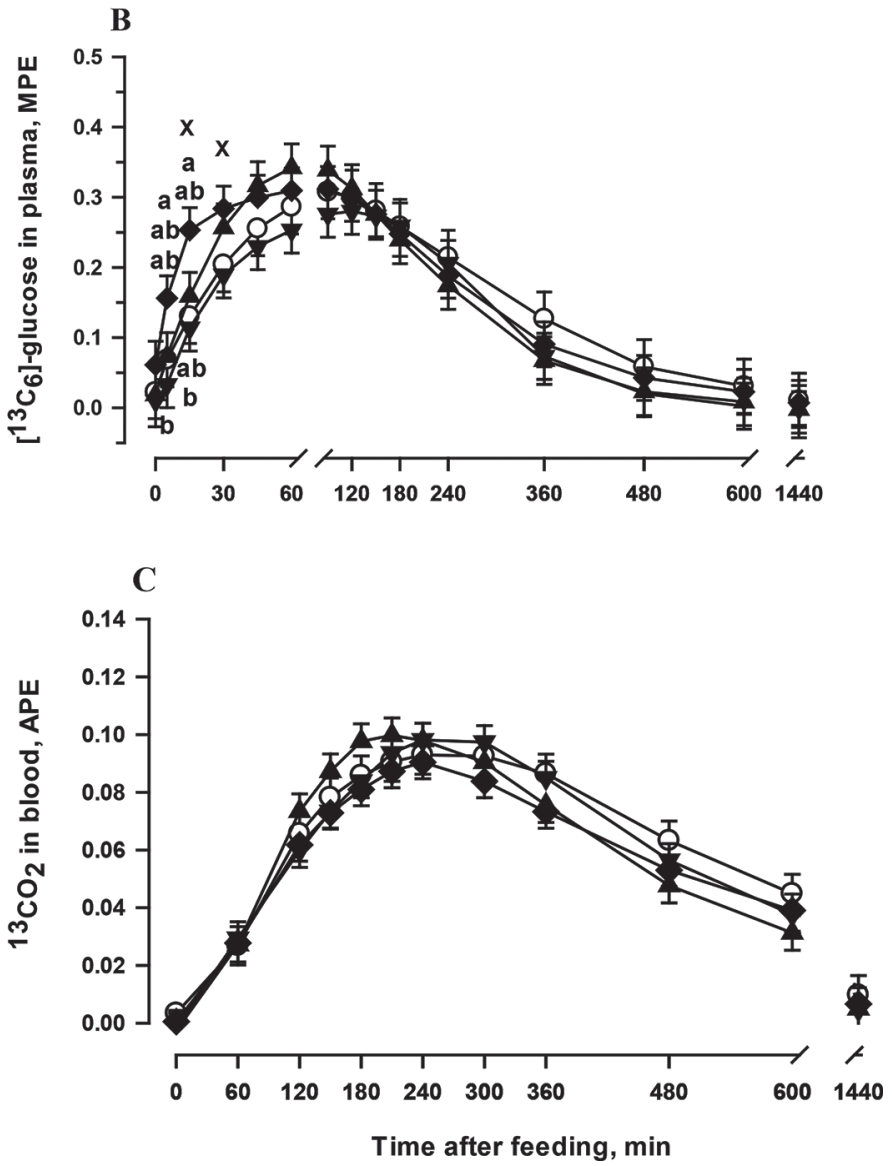

Figure 3. (A) Postprandial concentrations of xylose in plasma, (B) enrichment of ${ }^{13} \mathrm{C}_{6}$-glucose in plasma, and (C) enrichment of ${ }^{13} \mathrm{CO}_{2}$ in blood on d 4 of life in calves whose dams were supplemented with coconut oil (CTRL; $O ; n=6 ; 1$ calf was excluded due to fever), linseed and safflower oil (EFA; $\mathbf{\Delta} ; \mathrm{n}=7$ ), Lutalin (BASF SE; CLA; cis-9,trans-11 and trans-10, cis-12; $\mathbf{\nabla} ; \mathrm{n}=8 ; 1$ calf was excluded from statistical analyses of $\left[{ }^{13} \mathrm{C}_{6}\right]$-glucose due to technical difficulties), or EFA and CLA (EFA+CLA; Different letters $(\mathrm{a}, \mathrm{b})$ represent significant differences among groups at the same time point $(P<0.05)$. X indicates significant differences between EFA and non-EFA calves $(P<0.05)$. Significant effects $(P<$ $0.05)$ for xylose (time), enrichment of $\left[{ }^{13} \mathrm{C}_{6}\right]$-glucose (time and EFA $\times$ time interaction), and ${ }^{13} \mathrm{CO}_{2}$ (time). MPE $=$ mole percent excess; APE $=$ atom percent excess. 
Uken et al.: MATERNAL FATTY ACID SUPPLY IN CALVES

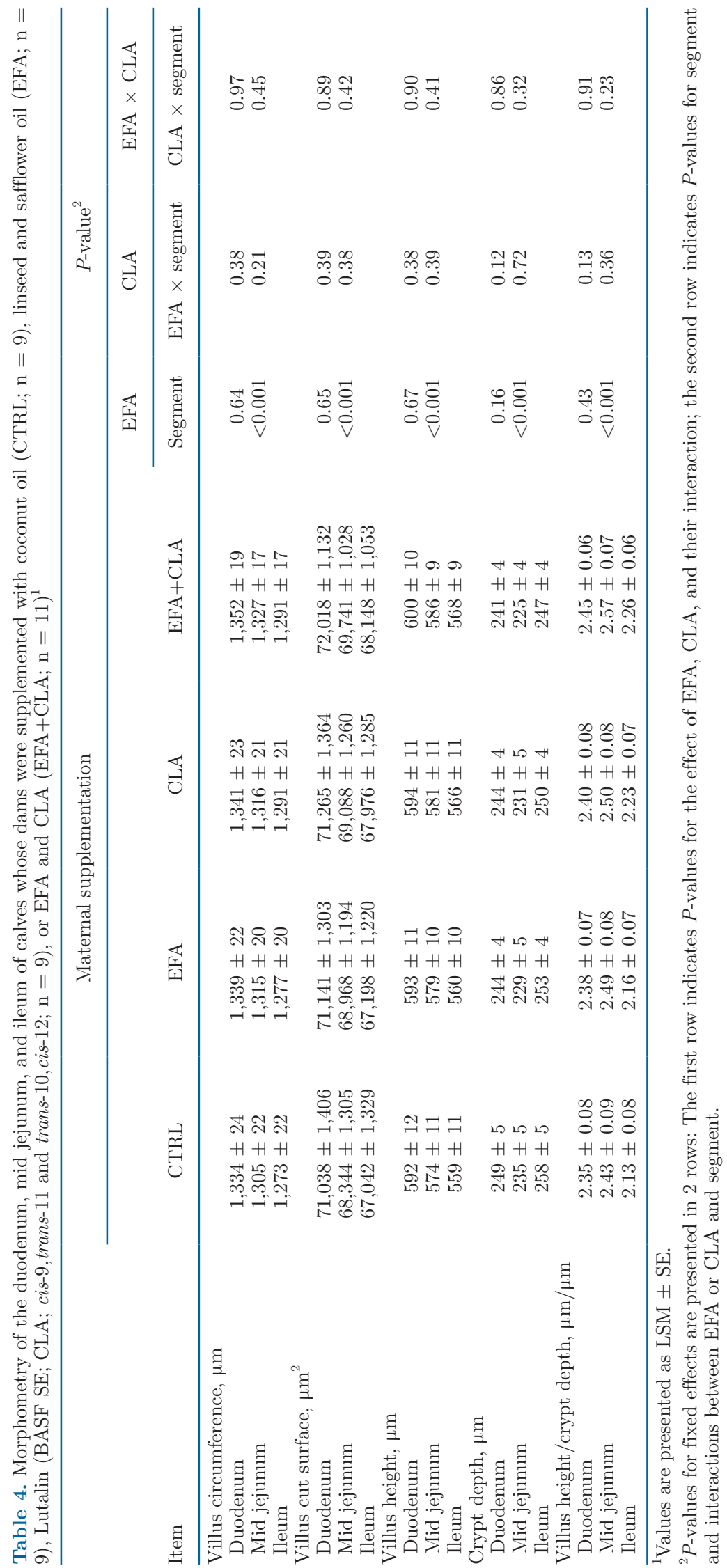


2003), the elevated plasma glucose concentrations we found in EFA calves could have been responsible for the higher plasma IGF-I concentrations in those calves. However, CLA treatment in our study indicated an inhibition of the EFA effect on plasma IGF-I. Previous studies in growing rats indicated that CLA might reduce plasma IGF-I levels, and that the combination of n-3 fatty acid and CLA supplementation could reduce concentrations of IGFBP-3, which probably decreased IGF-I binding capacity in blood plasma (Li et al., 1999). Plasma IGFBP-3 might also affect IGF-I levels in neonatal calves, but IGFBP-3 concentrations did not differ immediately after birth among groups in the present study. Furthermore, fetal plasma glucose stimulates plasma insulin (Oliver et al., 1996), and our data indicated a positive relationship between plasma concentrations of glucose and insulin in calves at term. However, we found no treatment effect of maternal EFA supplementation on plasma insulin in the calves immediately after birth. Interestingly, we found a significant overall negative correlation between maternal plasma IGF-I and plasma urea in calves at birth. Decreased plasma urea in calves might indicate reduced amino acid degradation and elevated fetal protein synthesis. We could not determine from this study whether maternal IGF-I affects fetal protein metabolism, but studies in sheep showed an effect of maternal nutritional status on insulin and IGF-I-induced protein synthesis in the fetus (Shen et al., 2005).

Plasma glucose concentrations immediately after birth were reduced and the RQUICKI was increased by maternal CLA treatment, indicating improved insulin sensitivity in calves when dams received CLA during late gestation (Holtenius and Holtenius, 2007). However, this result must be confirmed in further studies, because the effect of CLA on insulin sensitivity is not clear and depends on the specific CLA isomer (Taylor and Zahradka, 2004). Previous studies have indicated no increased insulin sensitivity (RQUICKI) with CLA treatment in cattle (Singh et al., 2014) but elevated insulin resistance in rats and humans (Risérus et al., 2002; Bezan, et al., 2018).

\section{Metabolic and Endocrine Changes Caused by Colostrum and Transition Milk Intake}

First colostrum milking contained high concentrations of IGF-I, leptin, and adiponectin, and all of those decreased with the onset of lactation, in accordance with previous findings (Blum and Hammon, 2000; Blum and Baumrucker, 2008; Kesser et al., 2015; Palin et al., 2017). Previous studies in cattle indicated no intestinal absorption of colostral IGF-I and insulin (Grütter and Blum, 1991; Vacher et al., 1995; Hammon and Blum,
1997), but an absorption of colostral IGFBP-4 was recently discussed in neonatal calves, and IGFBP-4 is enriched in bovine colostrum (Blum and Baumrucker, 2008; Meyer et al., 2017; Liermann et al., 2020). In addition, leptin and adiponectin were absorbed from colostrum in neonatal calves (Kesser et al., 2015, 2017; Liermann et al., 2020), and leptin was absorbed from colostrum in neonatal pigs (Palin et al., 2017). The relevance of the different behaviors of colostral endocrine factors for the maturation of newborn calves is not clear and is the subject of further investigation. Adiponectin and leptin from colostrum may affect intestinal development (Palin et al., 2017) and insulin sensitivity and responses in neonates (Havel, 2002; Palou et al., 2018; Liermann et al., 2020). In the present study, maternal fatty acid supplementation seemed to have no effect on the absorption of colostral endocrine factors, although we found slight stimulatory effects of EFA and CLA treatment on leptin and adiponectin concentrations in the first colostrum after parturition.

Nutrient intake with colostrum and transition milk feeding has been described in detail in a companion paper (Uken et al., 2021). Plasma total protein increased in all groups to more than $52 \mathrm{~g} / \mathrm{L}$, indicating sufficient immunoglobulin supply in all groups (Atkinson et al., 2017). The elevated plasma total protein concentration on d 2 of life in CLA calves was not a result of enhanced IgG absorption, because plasma IgG concentrations on $\mathrm{d} 2$ of life did not differ among the calves (K. L. Uken, E. Trevisi, and H. M. Hammon, unpublished observations). In contrast, EFA calves with low plasma total protein concentrations showed corresponding low plasma urea concentrations on d 2 of life. Because protein intake and $\operatorname{IgG}$ absorption were not different among groups but plasma IGF-I was elevated in EFA calves, this finding might indicate enhanced protein accretion in the EFA calves, because IGF-I stimulates protein synthesis in cattle (Breier et al., 2000; Hammon et al., 2012).

Basal plasma NEFA decreased and plasma triglycerides increased during the first days of life but did not indicate treatment effects of maternal fatty acid supplementation, although fat content in the colostrum on $\mathrm{d}$ 1 was highest in the CTRL dams. The slight increase in plasma NEFA from d 2 to d 3 of life in all groups was probably due to the low feed intake on d 2 to equalize the milk quantities between individual calves and adjust the milk feeding to 2 meals per $\mathrm{d}$ in the morning and evening from d 3 onward (Uken et al., 2021).

Changes in the basal plasma concentrations of glucose, lactate, and BHB during the first $5 \mathrm{~d}$ of life corresponded to the findings of previous studies in calves (Hammon and Blum, 1998; Frieten et al., 2017). The lower plasma BHB concentrations on d 4 in the CLA 
calves is hard to explain because BHB concentrations are generally very low in neonatal calves without a functional rumen (Frieten et al., 2017); these findings might indicate lower ketone body production in the livers of CLA calves. In contrast, the higher BHB concentrations in CTRL calves than in CLA calves on d 4 could be the result of increased oxidation of medium chain fatty acids from the coconut oil supplement given to the CTRL dams (Sato, 1994; Garcia et al., 2014). Although we found no effect on plasma glucose on d 2, the lower plasma glucagon concentrations and ratio of glucagon to insulin in EFA calves might have induced lower endogenous glucose production in those calves. Glucagon stimulates endogenous glucose production in calves (Hammon et al., 2012). A possible greater absorption of glucose from colostrum, as discussed below and shown in previous studies (Steinhoff-Wagner et al., 2011; Gruse et al., 2015), may have reduced the need for endogenous glucose production in the EFA calves.

Postprandial plasma glucose concentrations and glucose turnover, as well as first-pass uptake in splanchnic tissue, were not affected by maternal fatty acid supplementation at d 4 of life. The first-pass uptake of glucose decreased during the first week of life in neonatal calves, and our findings were within the previously published ranges (Steinhoff-Wagner et al., 2011; Gruse et al., 2015). The oral tracer study indicated faster $\left[{ }^{13} \mathrm{C}_{6}\right]$-glucose absorption during the first $30 \mathrm{~min}$ after feed intake in EFA calves. Interestingly, plasma glucose also reached its postprandial peak earlier in the EFA group than in all other groups. We can only speculate that maternal EFA supplementation may have influenced intestinal glucose absorption in calves. Previous findings in pigs indicated elevated intestinal glucose absorption when sows were supplemented with n-3 fatty acids (Gabler et al., 2007). An EFA deficiency resulted in impaired intestinal lactose digestion in mice (Lukovac et al., 2008). Furthermore, increased intake of n-3 fatty acids instead of monounsaturated or saturated fatty acids accelerated gastric emptying in women (Robertson et al., 2002). Thus, we cannot exclude the possibility that gastric emptying in the EFA calves was faster, allowing earlier absorption of the ingested glucose and higher plasma glucose concentrations shortly after feeding.

Although lactose intake (Uken et al., 2021; Supplemental Table S1, https://zenodo.org/record/4559652) and postprandial plasma glucose levels did not differ among groups on $\mathrm{d} 4$, the postprandial peak of plasma insulin was highest in the EFA and EFA+CLA calves. Because the ratio of glucose to insulin in plasma did not differ immediately after milk intake among the groups on d 4 (Supplemental Figure S2A, https://zenodo.org/ record/4559652), the greater insulin rise in plasma in the EFA and EFA+CLA calves might have been the consequence of elevated glucose absorption shortly after feeding. Plasma xylose, which is absorbed by the same intestinal route as glucose (Scharrer and Grenacher, 2000), did not differ among the groups at 60 and 120 min after milk intake. Morphometric measurements in the small intestine did not indicate differences in small intestinal absorptive capacity as a result of maternal fatty acid supplementation. The elevated ratio of villus height to crypt cell in the ileum of CLA calves might indicate enhanced intestinal maturation in the ileum due to maternal CLA treatment but was not related to intestinal glucose absorption in calves (Blättler et al., 2001; Steinhoff-Wagner et al., 2014). The decrease in plasma xylose after 360 min was faster in EFA calves than in CTRL calves. The xylose decrease in blood plasma might have started earlier in EFA calves because of faster xylose absorption, but plasma xylose also may have indicated an effect of maternal EFA supplementation on the xylose clearance rate in calf plasma.

Whole-body energy expenditure in calves as measured by $\mathrm{NaH}^{13} \mathrm{CO}_{3}$ was not affected by maternal fatty acid supplementation. With respect to postprandial energy metabolism, plasma NEFA levels did not decrease after feeding in CTRL calves on d 4, whereas the lowest postprandial NEFA concentrations were observed in EFA and CLA calves. Because NEFA levels indicate mobilization of body fat and NEFA release is inhibited by insulin (Hadorn et al., 1997; Kühne et al., 2000), the present finding corresponded to the elevated plasma insulin levels found in EFA calves. Maternal EFA supplementation also increased neonatal plasma leptin on d 4 and 5 of life. Leptin may stimulate insulin sensitivity in calves after feeding, because leptin is known for its insulin-sensitizing effects (Palou et al., 2018; Liermann et al., 2020). In addition, n-3 fatty acid supplementation improves insulin sensitivity in mice and in cattle (Pires et al., 2008; Fortin et al., 2010; Fan et al., 2020). Furthermore, postprandial plasma NEFA levels were temporarily lower in CLA calves than in CTRL calves, despite similar postprandial insulin levels between the 2 groups. This finding was surprising because energy intake did not differ among the groups. However, maternal CLA supplementation increased basal plasma adiponectin on d 3 and 4 of life during postprandial blood sampling. Adiponectin is known for its stimulatory effect on insulin sensitivity, which may also occur in calves (Havel, 2002; Liermann et al., 2020). This finding corresponds with the elevated RQUICKI in CLA calves at birth, as discussed above, and may indicate improved insulin sensitivity as a result of CLA supplementation. In contrast, CLA treatment, especially trans-10,cis-12 CLA, caused an insulin-resistant state in rodents, although only at very high dosages 
(Halade et al., 2010; Bezan et al., 2018). Therefore, the insulin-sensitizing potential of CLA is still controversial (Benjamin et al., 2015).

Postnatal growth and development in calves is regulated by the somatotropic axis, which is in turn affected by protein and energy intake (Breier et al., 2000; Hammon et al., 2012). Because protein and energy intake was comparable among the study groups, treatment effects on plasma concentrations of growth hormone, IGF-I, and IGFBP in calves were rarely observed. However, the ratio of IGFBP-3 to IGFBP-2 on d 2 of life increased most in EFA calves. The ratio of IGFBP-3 to IGFBP-2 indicates the nutritional energy supply and is a good proxy for validating nutrient status in cattle (Breier et al., 2000; Renaville et al., 2002; Vogel et al., 2021). Whether elevated EFA status led to improved nutrient absorption in newborn calves could not be determined from the present study. However, our findings indicated increased glucose absorption shortly after feeding, and elevated intestinal glucose absorption was described in piglets when sows were supplemented with n-3 fatty acids (Gabler et al., 2007). These findings indicate improved intestinal function in neonates with elevated n-3 fatty acid status. Previous findings have indicated elevated plasma concentrations of IGF-I associated with higher plasma glucose levels in calves fed milk replacer enriched with EFA during the preweaning period (Garcia et al., 2014). Furthermore, plasma growth hormone was elevated after feeding on d 4 in the EFA calves in the present study, potentially indicating a stimulated somatotropic axis as a result of EFA treatment. In contrast, CLA calves had lower plasma IGF-I concentrations than non-CLA calves throughout the study. This finding was surprising, because CLA treatment increased plasma IGF-I in early lactation in the dams (Vogel et al., 2021). A stimulatory effect of CLA supplementation in dairy cows is also supported by further studies (Csillik et al., 2017), but CLA treatment reduced plasma IGF-I concentrations in growing rats ( $\mathrm{Li}$ et al., 1999). Thus, variable effects of EFA and CLA on the somatotropic axis cannot be excluded, but the mechanisms behind these effects still need to be clarified.

\section{CONCLUSIONS}

The present data indicate that maternal EFA and CLA supply influences the energy metabolism of neonatal calves. Elevated plasma concentrations of glucose and IGF-I immediately after birth before first colostrum intake indicate enhanced placental nutrient transfer and improved energetic status in calves when dams received EFA supplementation. In addition, maternal supplementation with EFA and CLA during late gestation affected the concentrations of endocrine factors such as leptin and adiponectin in colostrum, but these differences did not result in different plasma leptin and adiponectin concentrations in calves after first colostrum intake. However, maternal EFA and CLA supplementation influenced postnatal and postprandial changes associated with energy metabolism. Maternal EFA and CLA supplementation probably improved neonatal insulin response by enhancing plasma adiponectin and leptin, but it did not promote the somatotropic axis in a consistent manner. More research is necessary to clarify the effect of maternal EFA and CLA supplementation on the endocrine regulation of neonatal energy metabolism. Furthermore, maternal fatty acid supplementation had only minor effects on the growth of intestinal mucosa in calves.

\section{ACKNOWLEDGMENTS}

We thank J. Gruse and S. Haubold, as well as the staff of the experimental animal facility and the cattle facility [Leibniz Institute for Farm Animal Biology (FBN), Dummerstorf, Germany] for experimental support. The laboratory work of H. Pröhl, C. Fiedler, C. Reiko, K. Karpati, E. Wünsche, U. Lüdtke, U. Wiedemuth, and P. Müntzel (FBN), as well as T. Blees (University of Bonn, Germany) and Y. Zbinden (University of Bern, Switzerland), is gratefully acknowledged. We also thank C. Höflich (Ligandis UG, Gülzow, Germany) for quantifying the IGFBP. We thank BASF (Ludwigshafen, Germany) for financial support of the study, which provided the dams for the present experiment. The publication of this article was funded by the Open Access Fund of the Leibniz Institute for Farm Animal Biology (FBN). The authors declare no conflicts of interest.

\section{REFERENCES}

Abuelo, A. 2020. Symposium review: Late-gestation maternal factors affecting the health and development of dairy calves. J. Dairy Sci. 103:3882-3893. https://doi.org/10.3168/jds.2019-17278.

Atkinson, D. J., M. A. G. von Keyserlingk, and D. M. Weary. 2017. Benchmarking passive transfer of immunity and growth in dairy calves. J. Dairy Sci. 100:3773-3782. https://doi.org/10.3168/jds .2016-11800.

Bauman, D., L. Baumgard, B. Corl, and J. Griinari. 2000. Biosynthesis of conjugated linoleic acid in ruminants. J. Anim. Sci. 77(ESuppl):1-15. https://doi.org/10.2527/jas2000.77E-Suppl1f.

Baumgard, L. H., B. A. Corl, D. A. Dwyer, A. Sæbø, and D. E. Bauman. 2000. Identification of the conjugated linoleic acid isomer that inhibits milk fat synthesis. Am. J. Physiol. Regul. Integr. Comp. Physiol. 278:R179-R184. https://doi.org/10.1152/ajpregu 2000.278.1.R179.

Benjamin, S., P. Prakasan, S. Sreedharan, A.-D. G. Wright, and F. Spener. 2015. Pros and cons of CLA consumption: An insight from clinical evidences. Nutr. Metab. (Lond.) 12:4. https://doi.org/10 .1186/1743-7075-12-4.

Bezan, P. N., H. Holland, G. S. de Castro, J. F. R. Cardoso, P. P. Ovidio, P. C. Calder, and A. A. Jordao. 2018. High dose of a con- 
jugated linoleic acid mixture increases insulin resistance in rats fed either a low fat or a high fat diet. Exp. Clin. Endocrinol. Diabetes 126:379-386. https://doi.org/10.1055/s-0043-118348.

Blättler, U., H. M. Hammon, C. Morel, C. Philipona, A. Rauprich, V. Rome, I. Le Huerou-Luron, P. Guilloteau, and J. W. Blum. 2001. Feeding colostrum, its composition and feeding duration variably modify proliferation and morphology of the intestine and digestive enzyme activities of neonatal calves. J. Nutr. 131:1256-1263. https://doi.org/10.1093/.jn/131.4.1256.

Blum, J. W., and C. R. Baumrucker. 2008. Insulin-like growth factors (IGFs), IGF binding proteins, and other endocrine factors in milk: Role in the newborn. Adv. Exp. Med. Biol. 606:397-422. https:// doi.org/10.1007/978-0-387-74087-4_16.

Blum, J. W., and H. Hammon. 2000. Colostrum effects on the gastrointestinal tract, and on nutritional, endocrine and metabolic parameters in neonatal calves. Livest. Prod. Sci. 66:151-159. https: //doi.org/10.1016/S0301-6226(00)00222-0.

Boesche, K. E., and S. S. Donkin. 2020. Pretreatment with saturated and unsaturated fatty acids regulates fatty acid oxidation in Madin-Darby bovine kidney cells. J. Dairy Sci. 103:8841-8852. https: //doi.org/10.3168/jds.2020-18802.

Boesche, K. E., and S. S. Donkin. 2021. Bovine pyruvate carboxylase gene proximal promoter activity is regulated by saturated and unsaturated fatty acids in Madin-Darby bovine kidney cells. J. Dairy Sci. 104:2308-2317. https://doi.org/10.3168/jds.2020-18803.

Boudry, G., V. Douard, J. Mourot, J. Lalles, and I. Le Huerou-Luron. 2009. Linseed oil in the maternal diet during gestation and lactation modifies fatty acid composition, mucosal architecture, and mast cell regulation of the ileal barrier in piglets. J. Nutr. 139:1110-1117. https://doi.org/10.3945/jn.108.102640.

Breier, B. H., M. H. Oliver, and B. W. Gallaher. 2000. Regulation of growth and metabolism during postnatal development. Pages 187-204 in Ruminant Physiology: Digestion, Metabolism, Growth and Reproduction. P. B. Cronjé, ed. CABI Publishing.

Burr, G. O., and M. M. Burr. 1930. On the nature and role of the fatty acids essential in nutrition. J. Biol. Chem. 86:587-621. https://doi .org/10.1016/S0021-9258(20)78929-5.

Couvreur, S., C. Hurtaud, C. Lopez, L. Delaby, and J.-L. Peyraud. 2006. The linear relationship between the proportion of fresh grass in the cow diet, milk fatty acid composition, and butter properties. J. Dairy Sci. 89:1956-1969. https://doi.org/10.3168/jds.S0022 -0302(06)72263-9.

Csillik, Z., V. Faigl, M. Keresztes, E. Galamb, H. M. Hammon, A. Tröscher, H. Fébel, M. Kulcsár, F. Husvéth, G. Huszenicza, and W. R. Butler. 2017. Effect of pre- and postpartum supplementation with lipid-encapsulated conjugated linoleic acid on reproductive performance and the growth hormone-insulin-like growth factor-I axis in multiparous high-producing dairy cows. J. Dairy Sci. 100:5888-5898. https://doi.org/10.3168/jds.2016-12124.

Donkin, S. S. 2016. Control of hepatic gluconeogenesis during the transition period. Pages 111-124 in Proc. 27th Annual Florida Ruminant Nutrition Symposium. Department of Animal Sciences, University of Florida, IFAS, Gainesville.

Ehrhardt, R. A., and A. W. Bell. 1997. Developmental increases in glucose transporter concentration in the sheep placenta. Am. J. Physiol. 273:R1132-R1141. https://doi.org/10.1152/ajpregu.1997 273.3.R1132.

Esselburn, K. M., K. M. O’Diam, T. M. Hill, H. G. Bateman 2nd, J. M. Aldrich, R. L. Schlotterbeck, and K. M. Daniels. 2013. Intake of specific fatty acids and fat alters growth, health, and titers following vaccination in dairy calves. J. Dairy Sci. 96:5826-5835. https://doi.org/10.3168/jds.2013-6608.

Fan, R., J. Kim, M. You, D. Giraud, A. M. Toney, S. H. Shin, S. Y. Kim, K. Borkowski, J. W. Newman, and S. Chung. 2020. alphaLinolenic acid-enriched butter attenuated high fat diet-induced insulin resistance and inflammation by promoting bioconversion of n-3 PUFA and subsequent oxylipin formation. J. Nutr. Biochem. 76:108285. https://doi.org/10.1016/j.jnutbio.2019.108285.

Ferlay, A., B. Martin, P. Pradel, J. Coulon, and Y. Chilliard. 2006. Influence of grass-based diets on milk fatty acid composition and milk lipolytic system in Tarentaise and Montbéliarde cow breeds.
J. Dairy Sci. 89:4026-4041. https://doi.org/10.3168/jds.S0022 -0302(06)72446-8.

Fortin, M., P. Julien, Y. Couture, P. Dubreuil, P. Y. Chouinard, C. Latulippe, T. A. Davis, and M. C. Thivierge. 2010. Regulation of glucose and protein metabolism in growing steers by long-chain n-3 fatty acids in muscle membrane phospholipids is dose-dependent. Animal 4:89-101. https://doi.org/10.1017/S1751731109991042.

Fowden, A. L., A. N. Sferruzzi-Perri, P. M. Coan, M. Constancia, and G. J. Burton. 2009. Placental efficiency and adaptation: Endocrine regulation. J. Physiol. 587:3459-3472. https://doi.org/10 .1113/jphysiol.2009.173013.

Frieten, D., C. Gerbert, C. Koch, G. Dusel, K. Eder, A. Hoeflich, B. Mielenz, and H. M. Hammon. 2018. Influence of ad libitum milk replacer feeding and butyrate supplementation on the systemic and hepatic insulin-like growth factor I and its binding proteins in Holstein calves. J. Dairy Sci. 101:1661-1672. https://doi.org/10 $.3168 /$ jds.2017-13603.

Frieten, D., C. Gerbert, C. Koch, G. Dusel, K. Eder, E. Kanitz, J. M. Weitzel, and H. M. Hammon. 2017. Ad libitum milk replacer feeding, but not butyrate supplementation, affects growth performance as well as metabolic and endocrine traits in Holstein calves. J. Dairy Sci. 100:6648-6661. https://doi.org/10.3168/jds.2017-12722.

Gabler, N. K., J. D. Spencer, D. M. Webel, and M. E. Spurlock. 2007. In utero and postnatal exposure to long chain (n-3) PUFA enhances intestinal glucose absorption and energy stores in weanling pigs. J. Nutr. 137:2351-2358. https://doi.org/10.1093/jn/137.11.2351.

Garcia, M., L. F. Greco, M. G. Favoreto, R. S. Marsola, D. Wang, J. H. Shin, E. Block, W. W. Thatcher, J. E. Santos, and C. R. Staples. 2014. Effect of supplementing essential fatty acids to pregnant nonlactating Holstein cows and their preweaned calves on calf performance, immune response, and health. J. Dairy Sci. 97:5045-5064. https://doi.org/10.3168/jds.2013-7473.

Gluckman, P. D., and C. S. Pinal. 2003. Regulation of fetal growth by the somatotrophic axis. J. Nutr. 133(Suppl 2):1741S-1746S. https: //doi.org/10.1093/jn/133.5.1741S.

Gruse, J., S. Görs, A. Tuchscherer, W. Otten, J. M. Weitzel, C. C. Metges, S. Wolffram, and H. M. Hammon. 2015. The effects of oral quercetin supplementation on splanchnic glucose metabolism in 1-week-old calves depend on diet after birth. J. Nutr. 145:24862495. https://doi.org/10.3945/jn.115.218271.

Gruse, J., E. Kanitz, J. M. Weitzel, A. Tuchscherer, T. Stefaniak, P. Jawor, S. Wolffram, and H. M. Hammon. 2016. Quercetin feeding in newborn dairy calves cannot compensate colostrum deprivation: Study on metabolic, antioxidative and inflammatory traits. PLoS One 11:e0146932. https://doi.org/10.1371/journal.pone.0146932.

Grütter, R., and J. W. Blum. 1991. Insulin and glucose in neonatal calves after peroral insulin and intravenous glucose administration. Reprod. Nutr. Dev. 31:389-397. https://doi.org/10.1051/rnd: 19910405.

Hadorn, U., H. Hammon, R. M. Bruckmaier, and J. W. Blum. 1997. Delaying colostrum intake by one day has important effects on metabolic traits and on gastrointestinal and metabolic hormones in neonatal calves. J. Nutr. 127:2011-2023. https://doi.org/10 $.1093 /$ jn/127.10.2011.

Halade, G. V., M. M. Rahman, and G. Fernandes. 2010. Differential effects of conjugated linoleic acid isomers in insulin-resistant female C57Bl/6J mice. J. Nutr. Biochem. 21:332-337. https://doi .org/10.1016/j.jnutbio.2009.01.006.

Hammon, H., and J. Blum. 1997. The somatotropic axis in neonatal calves can be modulated by nutrition, growth hormone, and Long-R-3-IGF-I. Am. J. Physiol. 273:E130-E138. https://doi.org/ 10.1152/ajpendo.1997.273.1.E130.

Hammon, H. M., G. Stürmer, F. Schneider, A. Tuchscherer, H. Blum, T. Engelhard, A. Genzel, R. Staufenbiel, and W. Kanitz. 2009. Performance and metabolic and endocrine changes with emphasis on glucose metabolism in high-yielding dairy cows with high and low fat content in liver after calving. J. Dairy Sci. 92:1554-1566. https://doi.org/10.3168/jds.2008-1634.

Hammon, H. M., and J. W. Blum. 1998. Metabolic and endocrine traits of neonatal calves are influenced by feeding colostrum for 
different duration or only milk replacer. J. Nutr. 128:624-632. https://doi.org/10.1093/jn/128.3.624.

Hammon, H. M., J. Steinhoff-Wagner, U. Schönhusen, C. C. Metges, and J. W. Blum. 2012. Energy metabolism in the newborn farm animal with emphasis on the calf: Endocrine changes and responses to milk-born and systemic hormones. Domest. Anim. Endocrinol. 43:171-185. https://doi.org/10.1016/j.domaniend.2012.02.005.

Harris, M. A., R. A. Hansen, P. Vidsudhiphan, J. L. Koslo, J. B. Thomas, B. A. Watkins, and K. G. Allen. 2001. Effects of conjugated linoleic acids and docosahexaenoic acid on rat liver and reproductive tissue fatty acids, prostaglandins and matrix metalloproteinase production. Prostaglandins Leukot. Essent. Fatty Acids 65:23-29. https://doi.org/10.1054/plef.2001.0283.

Havel, P. J. 2002. Control of energy homeostasis and insulin action by adipocyte hormones: Leptin, acylation stimulating protein, and adiponectin. Curr. Opin. Lipidol. 13:51-59. https://doi.org/10 .1097/00041433-200202000-00008.

Hill, T. M., H. G. Bateman 2nd, J. M. Aldrich, and R. L. Schlotterbeck. 2009. Effects of changing the essential and functional fatty acid intake of dairy calves. J. Dairy Sci. 92:670-676. https://doi .org/10.3168/jds.2008-1368

Holtenius, P., and K. Holtenius. 2007. A model to estimate insulin sensitivity in dairy cows. Acta Vet. Scand. 49:29. https://doi.org/ 10.1186/1751-0147-49-29.

Hötger, K., H. M. Hammon, C. Weber, S. Görs, A. Tröscher, R. M. Bruckmaier, and C. C. Metges. 2013. Supplementation of conjugated linoleic acid in dairy cows reduces endogenous glucose production during early lactation. J. Dairy Sci. 96:2258-2270. https:/ /doi.org/10.3168/jds.2012-6127.

Innis, S. 2005. Essential fatty acid metabolism during early development. Pages 235-274 in Biology of Growing Animals. Vol. 3. D. G. Burrin, ed. Elsevier Science.

Jarocka-Cyrta, E., N. Perin, M. Keelan, E. Wierzbicki, T. Wierzbicki, M. T. Clandinin, and A. B. Thomson. 1998. Early dietary experience influences ontogeny of intestine in response to dietary lipid changes in later life. Am. J. Physiol. 275:G250-G258. https://doi .org/10.1152/ajpgi.1998.275.2.G250.

Junghans, P., S. Görs, I. S. Lang, J. Steinhoff, H. M. Hammon, and C. C. Metges. 2010. A simplified mass isotopomer approach to estimate gluconeogenesis rate in vivo using deuterium oxide. Rapid Commun. Mass Spectrom. 24:1287-1295. https://doi.org/10.1002/ rcm.4509.

Junghans, P., J. Voigt, W. Jentsch, C. C. Metges, and M. Derno. 2007. The $13 \mathrm{C}$ bicarbonate dilution technique to determine energy expenditure in young bulls validated by indirect calorimetry. Livest. Sci. 110:280-287. https://doi.org/10.1016/j.livsci.2006.11.009.

Kaufmann, L. D., A. Munger, M. Rerat, P. Junghans, S. Gors, C. C. Metges, and F. Dohme-Meier. 2011. Energy expenditure of grazing cows and cows fed grass indoors as determined by the $13 \mathrm{C}$ bicarbonate dilution technique using an automatic blood sampling system. J. Dairy Sci. 94:1989-2000. https://doi.org/10.3168/jds 2010-3658.

Kay, J. K., J. R. Roche, E. S. Kolver, N. A. Thomson, and L. H. Baumgard. 2005. A comparison between feeding systems (pasture and TMR) and the effect of vitamin E supplementation on plasma and milk fatty acid profiles in dairy cows. J. Dairy Res. 72:322332. https://doi.org/10.1017/S0022029905000944.

Kesser, J., M. Hill, J. F. Heinz, C. Koch, J. Rehage, J. SteinhoffWagner, H. M. Hammon, B. Mielenz, H. Sauerwein, and H. Sadri. 2015. The rapid increase of circulating adiponectin in neonatal calves depends on colostrum intake. J. Dairy Sci. 98:7044-7051. https://doi.org/10.3168/jds.2015-9726.

Kesser, J., M. Korst, C. Koch, R. J. Romberg, J. Rehage, U. Müller, M. Schmicke, K. Eder, H. M. Hammon, H. Sadri, and H. Sauerwein. 2017. Different milk feeding intensities during the first 4 weeks of rearing dairy calves: Part 2: Effects on the metabolic and endocrine status during calfhood and around the first lactation. J. Dairy Sci. 100:3109-3125. https://doi.org/10.3168/jds.2016-11595.

Kühne, S., H. M. Hammon, R. M. Bruckmaier, C. Morel, Y. Zbinden, and J. W. Blum. 2000. Growth performance, metabolic and endocrine traits, and absorptive capacity in neonatal calves fed either colostrum or milk replacer at two levels. J. Anim. Sci. 78:609-620. https://doi.org/10.2527/2000.783609x.

Kurz, M. M., and L. B. Willett. 1992. The clearance of carbon-14-fructose, carbon-14-glucose, and carbon-14-sorbitol by calves at birth and 7 days of age. J. Dairy Sci. 75:236-246. https://doi.org/10 .3168/jds.S0022-0302(92)77758-3.

Li, Y., M. F. Seifert, D. M. Ney, M. Grahn, A. L. Grant, K. G. Allen, and B. A. Watkins. 1999. Dietary conjugated linoleic acids alter serum IGF-I and IGF binding protein concentrations and reduce bone formation in rats fed (n-6) or (n-3) fatty acids. J. Bone Miner. Res. 14:1153-1162. https://doi.org/10.1359/jbmr.1999.14.7.1153.

Liermann, W., C. T. Schäff, J. Gruse, M. Derno, J. M. Weitzel, E. Kanitz, W. Otten, A. Hoeflich, T. Stefaniak, H. Sauerwein, R. M. Bruckmaier, J. J. Gross, and H. M. Hammon. 2020. Effects of colostrum instead of formula feeding for the first 2 days postnatum on whole-body energy metabolism and its endocrine control in neonatal calves. J. Dairy Sci. 103:3577-3598. https://doi.org/10 .3168/jds.2019-17708.

Lukovac, S., E. L. Los, F. Stellaard, E. Rings, and H. J. Verkade. 2008. Essential fatty acid deficiency in mice impairs lactose digestion. Am. J. Physiol. Gastrointest. Liver Physiol. 295:G605-G613. https://doi.org/10.1152/ajpgi.90206.2008.

Madsen, B. D., M. D. Rasmussen, M. O. Nielsen, L. Wiking, and L. B. Larsen. 2004. Physical properties of mammary secretions in relation to chemical changes during transition from colostrum to milk. J. Dairy Res. 71:263-272. https://doi.org/10.1017/ s0022029904000263.

Metges, C. C., S. Görs, I. S. Lang, H. M. Hammon, K. P. Brussow, J. M. Weitzel, G. Nurnberg, C. Rehfeldt, and W. Otten. 2014. Low and high dietary protein:carbohydrate ratios during pregnancy affect materno-fetal glucose metabolism in pigs. J. Nutr. 144:155163. https://doi.org/10.3945/jn.113.182691.

Meyer, Z., C. Höflich, E. Wirthgen, S. Olm, H. M. Hammon, and A. Hoeflich. 2017. Analysis of the IGF-system in milk from farm animals-Occurrence, regulation, and biomarker potential. Growth Horm. IGF Res. 35:1-7. https://doi.org/10.1016/j.ghir.2017.05 .004 .

Mielenz, M., B. Mielenz, S. P. Singh, C. Kopp, J. Heinz, S. Häussler, and H. Sauerwein. 2013. Development, validation, and pilot application of a semiquantitative Western blot analysis and an ELISA for bovine adiponectin. Domest. Anim. Endocrinol. 44:121-130. https://doi.org/10.1016/j.domaniend.2012.10.004.

Moya-Camarena, S. Y., J. P. V. Heuvel, S. G. Blanchard, L. A. Leesnitzer, and M. A. Belury. 1999. Conjugated linoleic acid is a potent naturally occurring ligand and activator of PPAR $\alpha$. J. Lipid Res. 40:1426-1433. https://doi.org/10.1016/S0022-2275(20)33384-8.

Neuringer, M., W. E. Connor, D. S. Lin, L. Barstad, and S. Luck. 1986. Biochemical and functional effects of prenatal and postnatal omega 3 fatty acid deficiency on retina and brain in rhesus monkeys. Proc. Natl. Acad. Sci. USA 83:4021-4025. https://doi.org/ 10.1073/pnas.83.11.4021.

Odens, L. J., R. Burgos, M. Innocenti, M. J. VanBaale, and L. H. Baumgard. 2007. Effects of varying doses of supplemental conjugated linoleic acid on production and energetic variables during the transition period. J. Dairy Sci. 90:293-305. https://doi.org/10 .3168/jds.S0022-0302(07)72630-9.

Oliver, M. H., J. E. Harding, B. H. Breier, and P. D. Gluckman. 1996. Fetal insulin-like growth factor (IGF)-I and IGF-II are regulated differently by glucose or insulin in the sheep fetus. Reprod. Fertil. Dev. 8:167-172. https://doi.org/10.1071/rd9960167.

Palin, M. F., C. Farmer, and C. R. A. Duarte. 2017. Triennial Lactation Symposium/BOLFA: Adipokines affect mammary growth and function in farm animals. J. Anim. Sci. 95:5689-5700. https://doi .org/10.2527/jas2017.1777.

Palou, M., C. Pico, and A. Palou. 2018. Leptin as a breast milk component for the prevention of obesity. Nutr. Rev. 76:875-892. https: //doi.org/10.1093/nutrit/nuy046.

Perseghin, G., A. Caumo, M. Caloni, G. Testolin, and L. Luzi. 2001. Incorporation of the fasting plasma FFA concentration into QUICKI improves its association with insulin sensitivity in nonobese in- 
dividuals. J. Clin. Endocrinol. Metab. 86:4776-4781. https://doi .org/10.1210/jcem.86.10.7902.

Petzold, M., U. Meyer, S. Kersten, G. Breves, and S. Danicke. 2014. Feeding conjugated linoleic acids and various concentrate proportions to late pregnant cows and its consequence on blood metabolites of calves. Livest. Sci. 161:95-100. https://doi.org/10.1016/j livsci.2013.12.024.

Pires, J. A. A., J. B. Pescara, A. E. Brickner, N. Silva del Rio, A. P. Cunha, and R. R. Grummer. 2008. Effects of abomasal infusion of linseed oil on responses to glucose and insulin in Holstein cows. J. Dairy Sci. 91:1378-1390. https://doi.org/10.3168/jds.2007-0714.

Renaville, R., M. Hammadi, and D. Portetelle. 2002. Role of the somatotropic axis in the mammalian metabolism. Domest. Anim. Endocrinol. 23:351-360. https://doi.org/10.1016/s0739 $-7240(02) 00170-4$.

Risérus, U., P. Arner, K. Brismar, and B. Vessby. 2002. Treatment with dietary trans10cis12 conjugated linoleic acid causes isomerspecific insulin resistance in obese men with the metabolic syndrome. Diabetes Care 25:1516-1521. https://doi.org/10.2337/ diacare. 25.9.1516.

Robertson, M. D., K. G. Jackson, B. A. Fielding, L. M. Morgan, C. M. Williams, and K. N. Frayn. 2002. Acute ingestion of a meal rich in $\mathrm{n}-3$ polyunsaturated fatty acids results in rapid gastric emptying in humans. Am. J. Clin. Nutr. 76:232-238. https://doi.org/10 .1093/ajcn/76.1.232.

Sato, H. 1994. Plasma ketone levels in neonatal calves fed medium chain triglycerides in milk. J. Vet. Med. Sci. 56:781-782. https:// doi.org/10.1292/jvms.56.781.

Sauerwein, H., U. Heintges, M. Hennies, T. Selhorst, and A. Daxenberger. 2004. Growth hormone induced alterations of leptin serum concentrations in dairy cows as measured by a novel enzyme immunoassay. Livest. Prod. Sci. 87:189-195. https://doi.org/10 $.1016 / j$.livprodsci.2003.08.001

Schäff, C. T., J. Gruse, J. Maciej, R. Pfuhl, R. Zitnan, M. Rajsky, and H. M. Hammon. 2018. Effects of feeding unlimited amounts of milk replacer for the first 5 weeks of age on rumen and small intestinal growth and development in dairy calves. J. Dairy Sci. 101:783-793. https://doi.org/10.3168/jds.2017-13247.

Scharrer, E., and B. Grenacher. 2000. Na+-dependent transport of D-xylose by bovine intestinal brush border membrane vesicles (BBMV) is inhibited by various pentoses and hexoses. J. Vet. Med. A Physiol. Pathol. Clin. Med. 47:617-626. https://doi.org/ 10.1046/j.1439-0442.2000.00325.x.

Schönhusen, U., P. Junghans, A. Floter, J. Steinhoff-Wagner, S. Gors, F. Schneider, C. C. Metges, and H. M. Hammon. 2013. First-pass uptake and oxidation of glucose by the splanchnic tissue in young goats fed soy protein-based milk diets with or without amino acid supplementation: Glucose metabolism in goat kids after soy feeding. J. Dairy Sci. 96:2400-2412. https://doi.org/10.3168/jds.2012 $-5933$.

Shen, W., P. Wisniowski, S. C. Denne, D. W. Boyle, and E. A. Liechty. 2005. Anabolic effects of insulin and IGF-I in the ovine fetus are reduced by prolonged maternal fasting. Am. J. Physiol. Endocrinol. Metab. 288:E907-E913. https://doi.org/10.1152/ajpendo .00551 .2004

Shrestha, N., O. J. Holland, N. L. Kent, A. V. Perkins, A. J. McAinch, J. S. M. Cuffe, and D. H. Hryciw. 2020. Maternal high linoleic acid alters placental fatty acid composition. Nutrients 12:2183. https:/ /doi.org/10.3390/nu12082183.

Singh, S. P., S. Häussler, J. F. Heinz, B. Saremi, B. Mielenz, J. Rehage, S. Dänicke, M. Mielenz, and H. Sauerwein. 2014. Supplementation with conjugated linoleic acids extends the adiponectin deficit during early lactation in dairy cows. Gen. Comp. Endocrinol. 198:13-21. https://doi.org/10.1016/j.ygcen.2013.12.008.

Steinhoff-Wagner, J., S. Görs, P. Junghans, R. M. Bruckmaier, E. Kanitz, C. C. Metges, and H. M. Hammon. 2011. Intestinal glucose absorption but not endogenous glucose production differs between colostrum- and formula-fed neonatal calves. J. Nutr. 141:48-55. https://doi.org/10.3945/jn.110.128652.

Steinhoff-Wagner, J., R. Zitnan, U. Schönhusen, H. Pfannkuche, M. Hudakova, C. C. Metges, and H. M. Hammon. 2014. Diet effects on glucose absorption in the small intestine of neonatal calves: Importance of intestinal mucosal growth, lactase activity, and glucose transporters. J. Dairy Sci. 97:6358-6369. https://doi.org/10.3168/ jds.2014-8391.

Taylor, C. G., and P. Zahradka. 2004. Dietary conjugated linoleic acid and insulin sensitivity and resistance in rodent models. Am. J. Clin. Nutr. 79(Suppl):1164S-1168S. https://doi.org/10.1093/ ajcn/79.6.1164S.

Tyler, H., and H. Ramsey. 1993. Effect of fructose-induced hypoglycemia on cessation of macromolecular transport in the neonatal calf. J. Dairy Sci. 76:3021-3025. https://doi.org/10.3168/jds.S0022 -0302(93)77641-9.

Uken, K. L., C. T. Schäff, L. Vogel, M. Gnott, D. Dannenberger, S. Görs, A. Tuchscherer, A. Tröscher, W. Liermann, and H. M. Hammon. 2021. Modulation of colostrum composition and fatty acid status in neonatal calves by maternal supplementation with essential fatty acids and conjugated linoleic acid starting in late lactation. J. Dairy Sci. 104:4950-4969. https://doi.org/10.3168/ jds.2020-19627.

Vacher, P. Y. G. Bestetti, and J. W. Blum. 1995. Insulin-like growth factor I absorption in the jejunum of neonatal calves. Biol. Neonate 68:354-367. https://doi.org/10.1159/000244256.

Vicari, T., J. J. van den Borne, W. J. Gerrits, Y. Zbinden, and J. W. Blum. 2008. Postprandial blood hormone and metabolite concentrations influenced by feeding frequency and feeding level in veal calves. Domest. Anim. Endocrinol. 34:74-88. https://doi.org/10 .1016/j.domaniend.2006.11.002.

Vogel, L., M. Gnott, C. Kröger-Koch, D. Dannenberger, A. Tuchscherer, A. Troscher, H. Kienberger, M. Rychlik, A. Starke, L. Bachmann, and H. Hammon. 2020. Effects of abomasal infusion of essential fatty acids together with conjugated linoleic acid in late and early lactation on performance, milk and body composition, and plasma metabolites in dairy cows. J. Dairy Sci. 103:7431-7450 https://doi.org/10.3168/jds.2019-18065.

Vogel, L., M. Gnott, C. Kröger-Koch, S. Görs, J. M. Weitzel, E. Kanitz, A. Hoeflich, A. Tuchscherer, A. Tröscher, J. J. Gross, R. M. Bruckmaier, A. Starke, L. Bachmann, and H. M. Hammon. 2021. Glucose metabolism and the somatotropic axis in dairy cows after abomasal infusion of essential fatty acids together with conjugated linoleic acid during late gestation and early lactation. J. Dairy Sci. 104:3646-3664. https://doi.org/10.3168/jds.2020-19321.

White, H. M., S. L. Koser, and S. S. Donkin. 2011. Characterization of bovine pyruvate carboxylase promoter 1 responsiveness to serum from control and feed-restricted cows. J. Anim. Sci. 89:1763-1768. https://doi.org/10.2527/jas.2010-3407.

Wirthgen, E., C. Höflich, M. Spitschak, C. Helmer, B. Brand, J. Langbein, F. Metzger, and A. Hoeflich. 2016. Quantitative Western ligand blotting reveals common patterns and differential features of IGFBP-fingerprints in domestic ruminant breeds and species. Growth Horm. IGF Res. 26:42-49. https://doi.org/10.1016/j.ghir .2015.11.001.

Zitnan, R., J. Voigt, S. Kuhla, J. Wegner, A. Chudy, U. Schoenhusen, M. Brna, M. Zupcanova, and H. Hagemeister. 2008. Morphology of small intestinal mucosa and intestinal weight change with metabolic type of cattle. Vet. Med. 53:525-532. https://doi.org/10 .17221/1968-VETMED.

\section{ORCIDS}

K. L. Uken (® https://orcid.org/0000-0002-4877-7690 A. Hoeflich @ https://orcid.org/0000-0003-2018-2836 J. M. Weitzel ๑ https://orcid.org/0000-0002-4073-6691 A. Tröscher (ํ) https://orcid.org/0000-0002-4198-4427

H. Sauerwein () https://orcid.org/0000-0002-6905-4053

R. M. Bruckmaier ๑ https://orcid.org/0000-0002-9374-5890

J. J. Gross @ https://orcid.org/0000-0002-2578-6076

H. M. Hammon ๑ https://orcid.org/0000-0001-8698-1257 